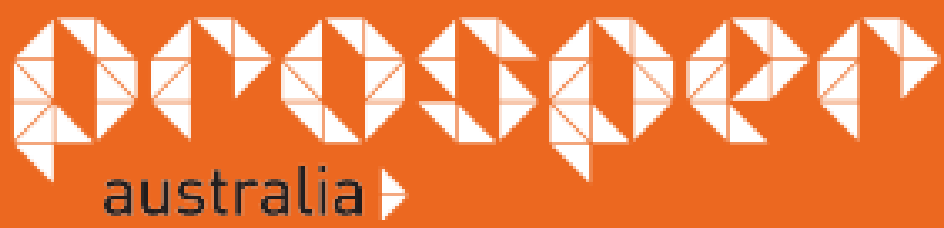

\section{THE FIRST INTERVAL}

Evaluating ACT's Land Value Tax Transition
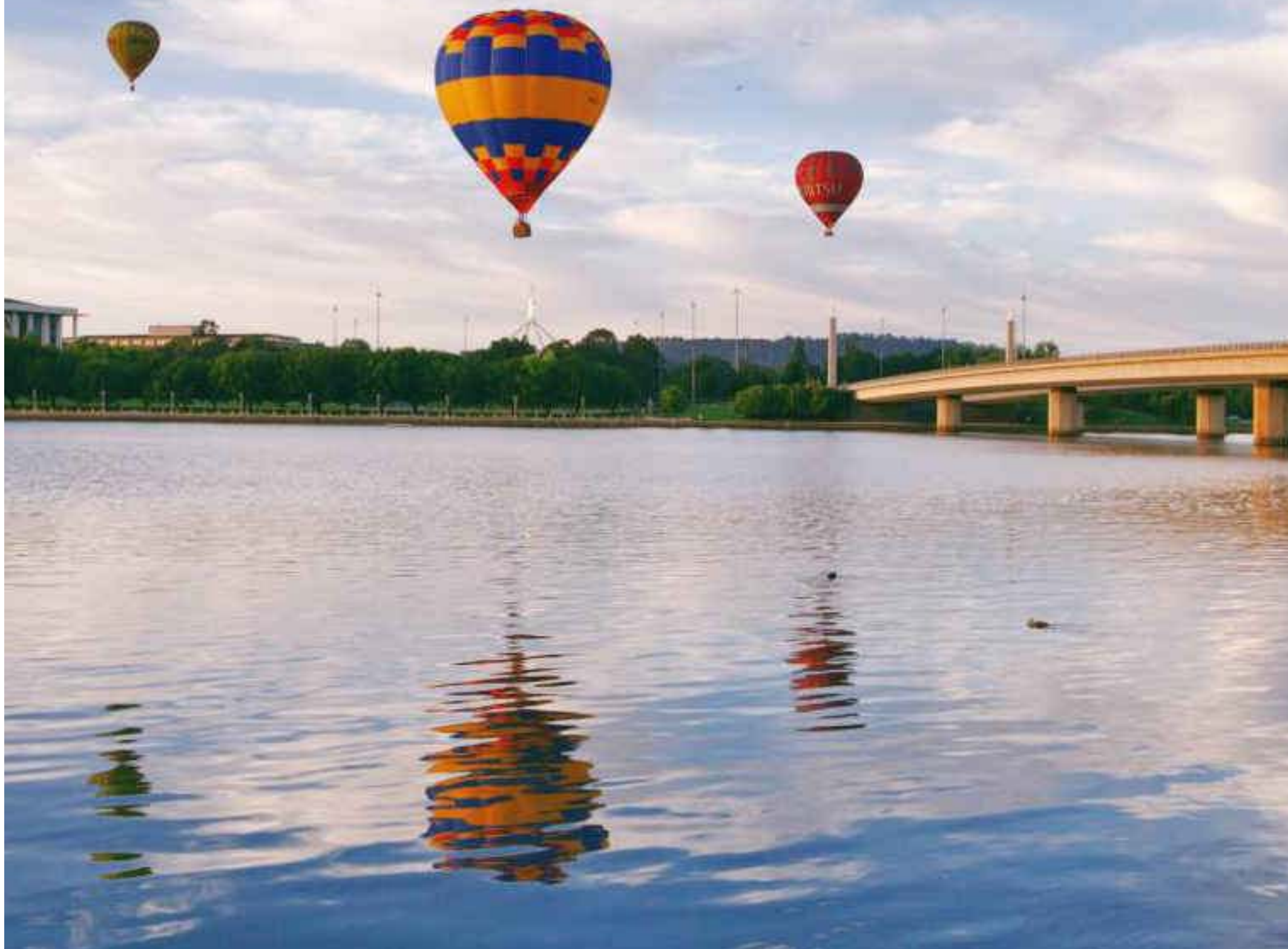


\section{About Prosper Australia}

Prosper Australia is a non government think tank and tax reform lobby group inspired by economic efficiency and social justice that advocates for the fair distribution of land and natural resource rents.

\section{Contact}

Prosper Australia

64 Harcourt Street

North Melbourne Vic 3051

Tel: +61 (0)3 93284792

progress@prosper.org.au 


\section{Contents}

Contents

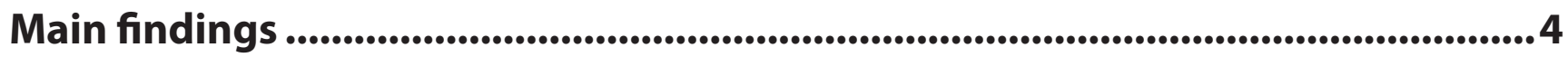

Executive Summary.....................................................................................................................................5

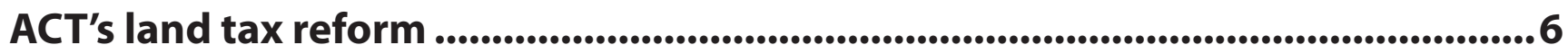

Governance of land the ACT way ..................................................................................................7

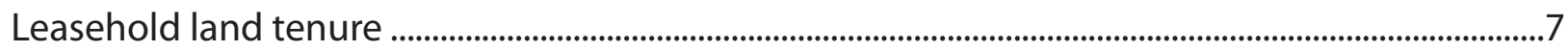

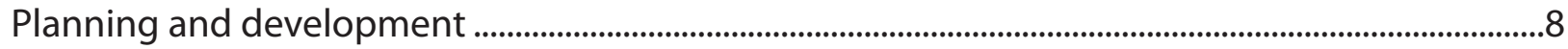

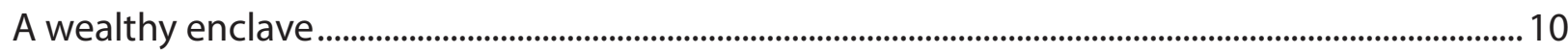

Summary of land tax reforms ........................................................................................................11

Summary of related reforms..................................................................................................13

Analysis of reforms

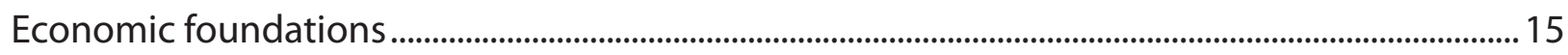

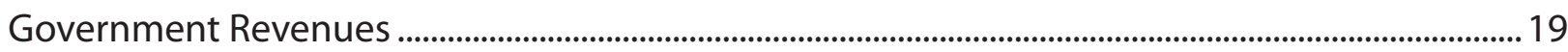

Residential property ownership market........................................................................................... 21

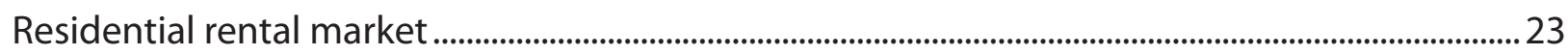

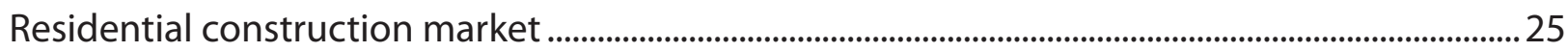

Further considerations as reform progresses .............................................................................................2

Experiment lessons ..............................................................................................................................29

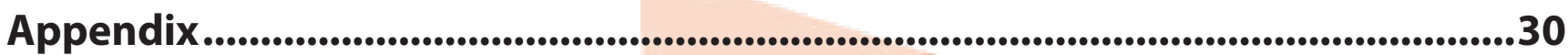




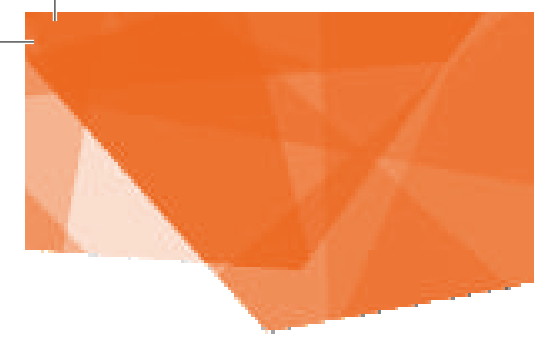

\section{Executive Summary}

In 2012 the Australian Capital Territory (the Territory) began a multi-decade task of major land tax reform to exchange taxes on transactions for taxes on the economic rents that accrue to landholders. This report evaluates the economic effects of these changes at the first interval, 2016, to tease out potential lessons from this rare policy experiment.

Economic theory suggests these reforms will, over time, provide greater incentives for landholders to invest in buildings and improvements. Meanwhile, the distribution of who pays is changing substantially. Rather than falling only on those who sell property, every holder of a Territory land lease will pay higher land taxes, in the form of a general rates charge, every year. For some landholders, this changes their annual cash flows substantially, supporting the need for a long and slow transition.

This report assesses the effects of these reforms to date in terms of government revenue, dwelling prices, rents, turnover, housing finance, new construction and other related metrics. It reveals that much of the anticipated future tax obligations appear to have been already capitalised into lower land prices. Additionally, the tax transition may have also deterred speculative buyers from the housing market, adding even further to the recent pattern of low and stable property prices in the Territory. Because of the price effect of the land tax, a typical new home buyer in the Territory will save between $\$ 1,000$ and $\$ 2,200$ per year on mortgage repayments.

In terms of forecasting the effects over the remaining transition period, this initial assessment suggests that since expectations of higher tax obligations appear to have already been factored into prices, the primary ongoing effect will be on the cash flow of commercial property owners, and owners of high value residential property, who are likely to see faster increases in their land value taxes. Because of this, we may expect political pressure to modify the transition path of marginal land tax rates in the remaining reform period.

The main lesson is that a transition to a land value tax system can be achieved without radical disruption to property markets, and will have the added benefit of reducing speculative buying and dampening price cycles. The Territory's unique leasehold tenure system and development provisions, that ensure that all land leased to the private market is utilised for its lease purpose within two years, already provides many of the development incentives that a broad-based land tax would bring should it be adopted in other jurisdictions that lack these features. Therefore, a transition towards land value taxes elsewhere would likely lead to noticeable increases on new housing construction and lower rental prices.

A final lesson is that the Territory betterment tax system, in the form of a Lease Variation Charge and sale of new land leases via the Land Development Authority, is a working example of a successful scheme to sell new planning rights in an economically efficient way, and avoiding billion dollar give-aways to private developers; a system that is complementary to a land value tax scheme and if implemented nationally would generate around $\$ 11$ billion in government revenue per year. 


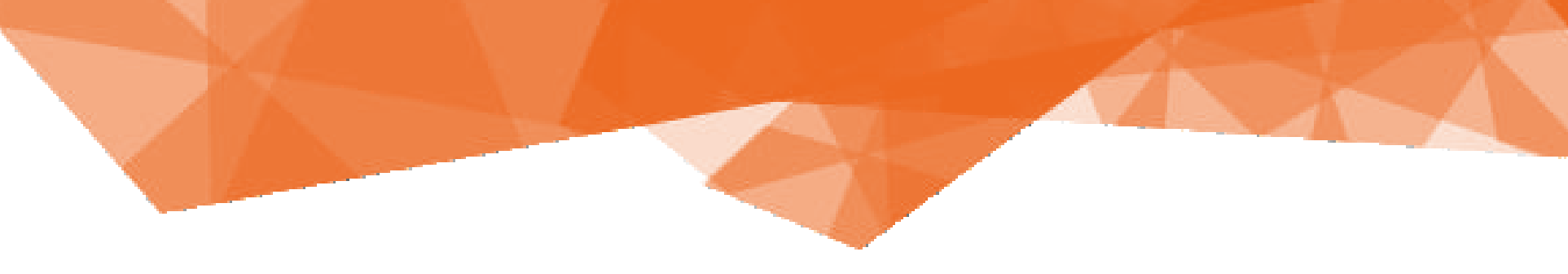

\section{ACT's land tax reform}

\section{The 2012 turning point}

For the Australian Capital Territory (the Territory), 2011-12 was the start of a tremendous transition period for their taxation and regulation of land. The release of the ACT Taxation Review $^{i}$ (the Review) in May of 2012 demonstrates the appetite for transformational changes to the tax system. A major element of the Review was its emphasis on shifting away from duties on property transfers, and towards recurring land value taxes. Recommendation 2 of the Review was:

With regards to long-term structural reform, over a period of time that is adequate for appropriate transition:

- abolish duty on conveyances

- retain a form of tax on payroll to maintain a diversified tax system

- abolish duty on general insurance and life insurance, and

- $\quad$ adopt a broad-based land tax as a base for revenue replacement.

This recommendation echoed the 2010 Henry Tax Review ${ }^{\text {ii }}$, which advanced the idea that States and Territories would benefit from shifting their revenue streams towards more efficient land value taxes (LVTs).

In practice, this has led to the Territory's previous land value tax system, which exempted owner-occupied residential land, being phased out in favour of a single general rates charge levied on the value of all land. The net effect is to reduce the administration of land taxation by eliminating one tax, and broaden its base by applying land value taxes to all property types. Over the proposed twenty-year transition period, increases in the general rates are intended to offset declines in government revenue from the removal of other taxes, such duties on general insurance, life insurance, and property transfers.

A number of social and economic objectives were sought by the land tax reforms of this period, which were highlighted in the Review. The main overarching factors were

i) the political consideration of increased revenue independence of the Territory, which only raised $25 \%$ of its revenue through direct taxation in 2010,

ii) improvement in the efficiency and transparency of the territory's taxation system, and

iii) greater equality in territory taxation.

Many specific objectives were nested within the overarching ones. For example, one objective outlined in the Review was for increased densification to provide efficiency benefits of lower infrastructure costs for new dwellings and commercial uses and meet equity objectives by charging rates based on the value of the consumption of land.

Other changes were made in this reform period in order to meet these objectives. One was to limit new entrants to the previous Land Rent Scheme which had allowed households to pay an annual rental to the ACT Government of 


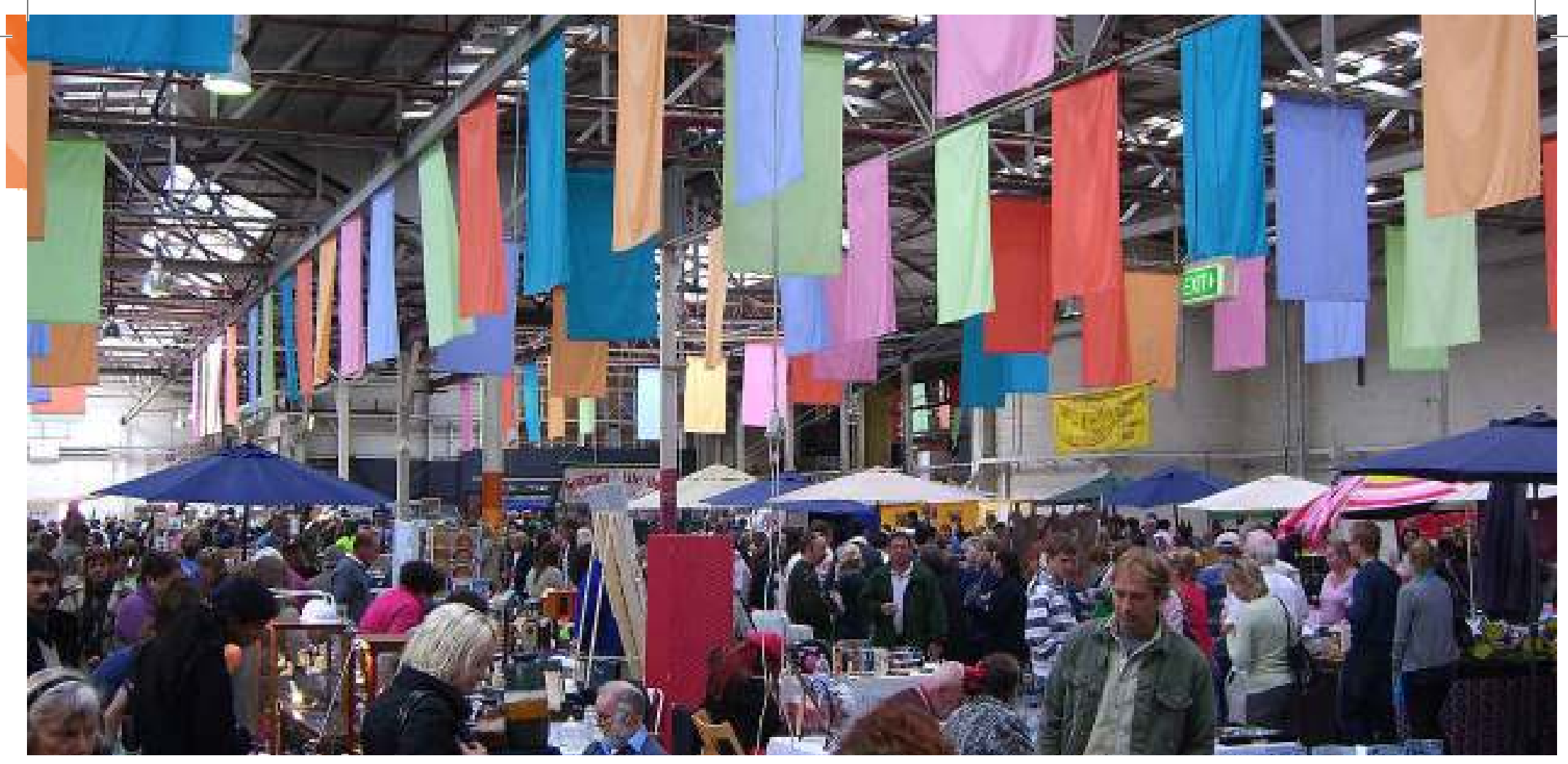

$4 \%$ of land value as an alternative to buying new land leases upfront from the government at their full market value. In October 2013 the Scheme was restricted to households with a total income of less that $\$ 160,000$, and with a discounted land rent rate of $2 \%$. Since 2011, 2,643 households have taken up this scheme, of which 1,075 are at the discounted rate. A second change was to introduce the Over 60s Home Bonus Scheme in 2014, which reduced the stamp duty payable by qualifying non-pensioners aged over 60 , who own their own home and are moving to more suitable accommodation. The changes sought to further improve the equity and efficiency of the housing market in the Territory.

A summary of the tax reforms made in 2012 is available from the ACT Treasury ${ }^{\mathrm{iii}}$ In all, the period of land tax reform that began in 201112 , and will continue for decades, is an important policy experiment of global significance.

\section{Governance of land the ACT way}

The Territory's land title system is unique. A short digression into the history of this system, and relevant legal and economic attributes of the Territory system, are discussed here.

\section{Leasehold land tenure}

Land titles in the Territory are leasehold, with residential leases being 99 years. Such tenure systems are common in rural areas of other states, as pastoral leases, yet only by historical happenstance does the Territory have a fully leasehold system. ${ }^{\text {iv }}$ Current policy on expiry of a residential lease is as follows:

Provided that the land is not required by either the Territory or Commonwealth, the Territory will grant a new residential lease towards the end of the 99 years, to the person holding the old residential lease, without payment (other than an administrative fee). 


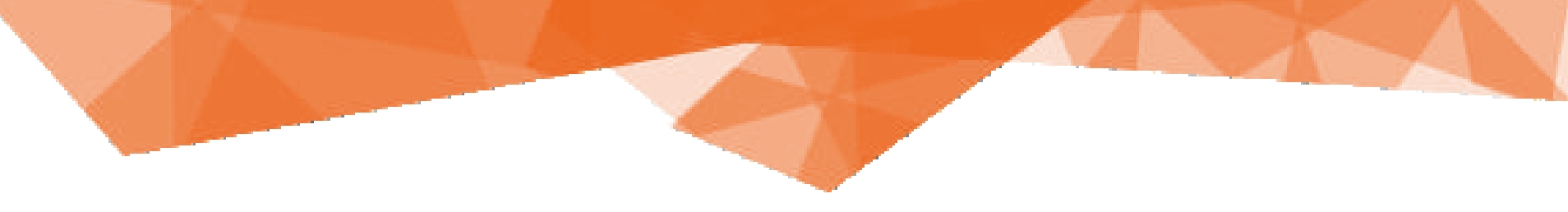

The Territory's current system is a product of the prevailing nation-building mood and economic ideals soon after the Federation of Australian in 1901. In 1911 the land that makes up the Territory was transferred to the Commonwealth from New South Wales. Following deliberations on how to fund and build the new capital city, the City Leases Ordinance 1921 was passed allowing for the release of land to private lessees for periods not exceeding 99 years, and with conditions on the annual land rent and frequency of revaluation. In this way the fledging government could raise the revenue required to build the new city infrastructure from the sale of leases to private owners, while retaining tight control on the growth and design of the city.

The Territory's unique leasehold tenure system also lends itself to creative ways of provisioning land for private sector use. For example, the Land Rent Scheme allowed buyers to rent land, rather than purchase it upfront from the government, decreasing the upfront cost of home ownership. Though freehold title systems do not preclude such schemes in other States, the history and experience with the leasehold tenure system seems to expand the publicly and politically acceptable scope of land and housing policy in the Territory.

In keeping with the philosophy of their leasehold system, the Land Development Agency (LDA) is a government body that performs the function of selling public land (new land leases) to private owners in specific areas in keeping with its published long term plan, which is to release 13,500 new residential lots to market before 2018-19. This function allows the Territory government the flexibility to directly implement their town planning outcomes by releasing land for development to the public in a particular order, ensuring that development and city expansion proceeds in an efficient manner. It also generates substantial revenues from these land sales, which were $\$ 354$ million in the financial year 2014-15, from the sale of 3,669 residential dwelling sites, providing a dividend to the Territory government of $\$ 164$ million. For perspective, the size of that dividend was $12 \%$ of total tax revenue in 201415. The dividend revenue from the LDA can therefore be considered the result of a system that fully captures the betterment from converting the land to higher value uses, which is net of their investment in subdivision infrastructure. In other jurisdictions these gains would accrue to private developers given planning permission for similar development.

\section{Planning and development}

The Territory has no local council layer of government. This feature of the political system is possibly a key reason why such radical changes to land taxation were able to be implemented. In other states, general rates are typically levied by the local council, while land taxes are levied by the state government. State governments could unilaterally modify their land tax systems to apply more broadly, and at a higher rate, to replace stamp duties. But there is an argument that public dissatisfaction with multiple levels of government levying taxes on the identical base would mean that additional political cooperation between council and state government would be necessary for similar reforms to be adopted elsewhere.

While there are no councils in the Territory, the government still performs the major functions typically undertaken by councils in other states. One function relevant to this report is town planning. Zoning controls, which limit density and types of uses in certain locations, are implemented though the Territory Plan 2008, and numerous subordinate neighbourhood plans. Thus, the analysis of the land tax reform in this report remains highly applicable 
to other States and cities with substantial zoning controls such as development limits, and minimum requirements for complying development. Outside of this plan, the National Capital Plan is an additional strategic plan for the Territory which ensures that areas of national significance are preserved and enhanced in a fitting manner.

Not only does the Territory government fulfil planning and development roles, but it has strict policies in relation to development of vacant land. Section 298 of the Planning and Development Act 2007 allows for the requirement that the first lessee of a new land lease cannot on-sell their lease without meeting the development provisions of the lease, which typically require them to construct a building that complies with the lease purpose within two years." An extension of time can be applied for under extenuating circumstances, such as financial hardship. This means that in practice there are no private vacant new residential land sales in the ACT; all vacant land is either under a rural lease and being used for that purpose, or is fully controlled by the Territory government and is available to be leased in the future to private owners for specific purposes. Once a lease has been created and sold to the private sector, and a building constructed for the purpose given on the lease, a variation on the use of the lease can be sought by the lessee from the Environment and Planning Directorate. For example, the owner of a lease for the purposes of a single residential dwelling may wish to develop the block into four townhouses. They will make an application to vary their lease conditions, and if this new use complies with the Territory Plan 2008, they will be granted a variation, allowing for the old or new purpose to be undertaken in the site, subject to the payment of a Lease Variation Charge. In essence, the betterment, or the new development rights, are sold by the Territory to lessees, who have the right, but not obligation to develop in accordance with the new use.
The Territory has had a betterment tax in place since 1971, and with the passing of the Planning and Development (Lease Variation Charges) Amendment Act 2011, the betterment tax was renamed the Lease Variation Charge (LVC), with the amounts payable now codified into a schedule of applicable charges for specific lease variations in each suburb, either on a per dwelling (for residential use types), or per floor area (for commercial uses) basis. Non-scheduled lease variations still revert back to the previous system, which calculated the betterment charge at $75 \%$ of the land value gains. The scheduled LVC values are determined by valuers, and may be periodically updated to reflect changes in market values. The intention of this codification of betterment taxes was to provide greater upfront certainty for developers on project feasibility.

Because of the lack of developer interests in land-banking, the primary target of the property development lobby in the Territory is the betterment tax. In effect, "planning gains", which sustain the abnormally profits of property developers in other states, are greatly reduced, removing the temptation and ability to provide political favours by changing town planning rules.

The territory system could be argued to reduce the choice of new buyers to buy vacant land and build their home. On 19th May 2016, for example, there were 19 vacant residential sites advertised in the Territory on realestate.com. au that were not new land leases for sale by the LDA. These were the result of recent house demolitions as part of The Loose Fill Asbestos Insulation Eradication Scheme ("buy-back program"); a scheme that will result in ongoing buy-backs, demolitions, and re-sales of residential land leases. By comparison, Queensland on that date had over 22,000 vacant residential land sites advertised ( $87 \mathrm{x}$ as many sites on a per capita basis), in New South Wales over 


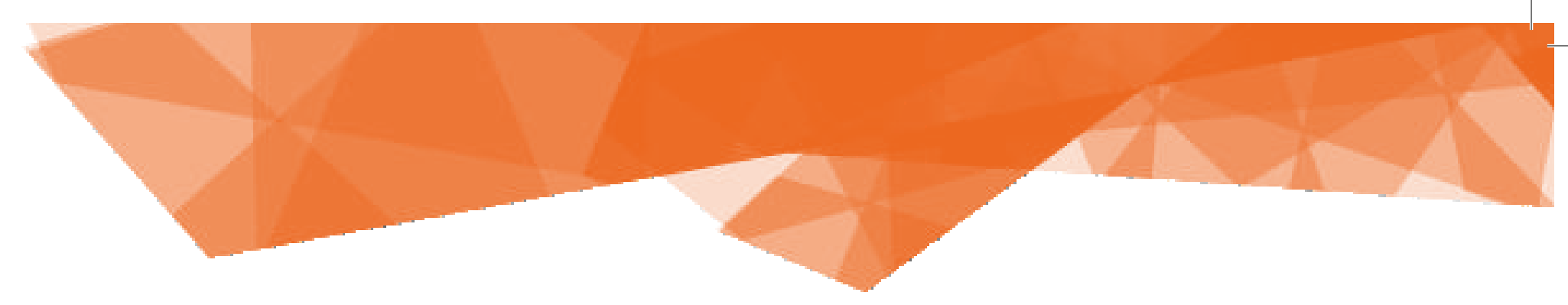

10,000 (27x as many sites per capita), and in Victoria over 13,000 vacant sites (45x as many sites per capita). This seems restrictive on the surface. Yet homebuyers have similar options to build new homes in the Territory as in other states. Their current options are to either purchasing a new land lease from the LDA, buy a vacant site from the buy-back program, or buying an existing home and become one of the approximately 2,500 knock downs and rebuilds in Canberra each year. ${ }^{\text {vii }}$ The main difference between this and other states is that the LDA is a public, not a private, developer.

The fact that the Territory has no private vacant land market, along with its comprehensive betterment tax system, is important. One of the main economic benefits of shifting to a land value tax system is to create financial pressure on owners of land, especially vacant land, to bring their land into higher value uses. This incentive arises when land tax is levied on land value at its highest and best use, which is different from the current land use. In the Territory however, because of the LVC, the current use and highest and best use values of land leases are always close. There is also no vacant land. Thus these incentive effects from introducing a higher rate of land value tax are likely to be far more subdued in the Territory. Instead, the Territory practice of selling new leases with development provisions provides an alternative investment incentive that is lacking in other states.
As a final point, one reason that owner-occupied residences are exempt from land value taxes is that there can be cases where homeowners inadvertently fall in an area that a council rezones for higher value uses, which makes them liable to pay a land tax based on the value for that new higher value use. Because zoning controls can have such large effects on land values, this situation is usually considered to be unfair, especially as it can lead to governments using rezoning as a tool for generating higher tax revenues. To avoid this situation prescribed land valuation methods can be modified to ensure that residential land is valued as if the current use is the highest and best use.

\section{A wealthy enclave}

Another relevant factor when considering the widespread applicability of the Territory's experiment with land tax reforms is that they occurred in one of the wealthiest parts of Australia, where median gross household income is $42 \%$ higher than the national average. ${ }^{\text {viii }}$ Not only do households in the Territory have higher incomes, there is much greater equality of incomes, with a Gini coefficient ${ }^{\text {tix }}$ of 0.37 compared to 0.45 for the country as a whole. Lastly, the composition of the workforce is highly skewed towards the public sector, with 50\% public sector jobs, compared to $26 \%$ nationally. Translating these reforms to other States requires acknowledging that additional safeguards for income poor homeowners may be necessary, along with other support mechanisms during the transition period. 

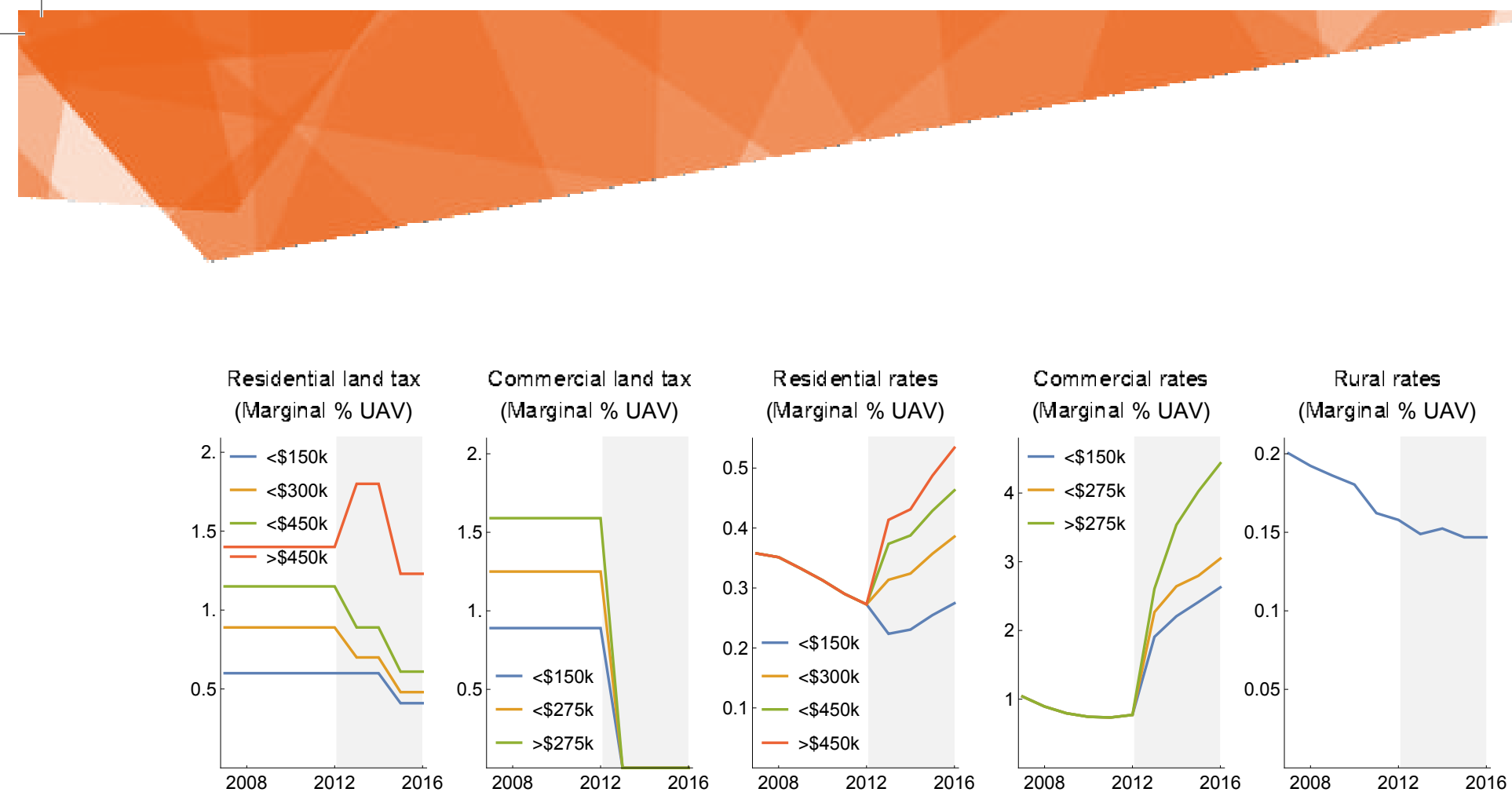

Source: Taxation Administration Act 1999. Disallowable instruments under Section 139: Taxation Administration (Rates) Determinations, 2007-2015, and Taxation Administration (Land Tax) Determinations, 2007-2015.

\section{Summary of land tax reforms}

Figure 1 summarises the changes in applicable marginal rates of land value tax and general rates prior to, and since, the beginning of the tax transition period (shading shows the tax reform period). Both rates and land value taxes are charged on a rising block scale on the basis of the Average Unimproved Value (AUV), which is the average of the past three year's assessed land values. Owners of higher value properties have higher average rates obligations compared to land values, in a progressive system that mirrors the approach to income taxes.

The left two panels of Figure 1 show the marginal rates of land value tax for owners of tenanted dwellings (not owner-occupied residential property) and commercial property. These land value taxes are being incrementally phased out for all residential property at all values, but were cut entirely for commercial property in 2012 and immediately replaced through higher general rates.
Panels three to five show the marginal tax rate at which general rates are levied for residential, commercial and rural property. What can be seen here is that the changes to residential property are much slower - in keeping with the slower reduction in land value taxes - while for commercial property all tax rates saw a substantial jump in the first year of the transition, and are now rising more slowly. For rural property, which has no land tax obligation, the tax rate for general rates has continued its slow fall during the transition period since 2012.

In addition to general rates levied on land values, the Territory also has a fixed charge portion of the general rates scheme which has been incrementally increased for all land use types; from $\$ 555$ in 2012-13 to \$730 in 2015-16 for each residential property, from $\$ 1213$ to $\$ 2130$ for each commercial property, and $\$ 126$ to $\$ 150$ for each rural property.

The net effect of these changes on the tax obli- 


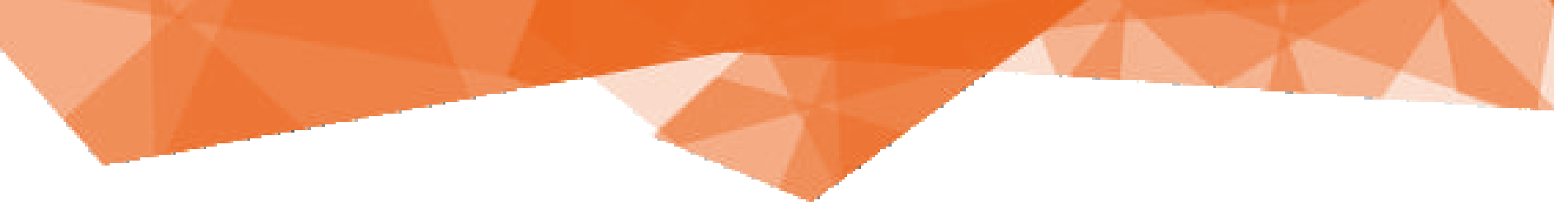

gations of owners of different property is shown in the panel of charges in Figure 2. On the left side are the total obligation of land values taxes and general rates for owners of commercial property and investment homes. The largest financial impact of this reform is clearly on owners of commercial property, where a property with a land value of $\$ 600,000$ has seen an increase in tax payable of $\$ 15,000$ between 2012 and 2016, or a 109\% increase if the land value stayed constant.

Owners of residential investment property have seen the combined rates and land value tax obligation stay relatively constant, as the reduction in general rates roughly offsets the increase in land value taxes.
In the right two panels are the annual general rates amount for owner-occupied residential property and rural property. Owner occupied housing now carries a larger tax obligation, particularly for higher value homeowners, where those with land values of $\$ 800,000$ are paying around $\$ 1,200$ more each year compared to 2012. Near the median land value, the increase is far lower, or about $\$ 500$ a year higher. Rural landowners gain overall, with ongoing reductions in their tax obligations. Overall the tax transition period appears heavily skewed towards shifting the tax burden between owners of different property types; away from rural property, and mostly towards commercial property, leaving the average homeowner with little change, and high value homeowners with a larger tax burden.

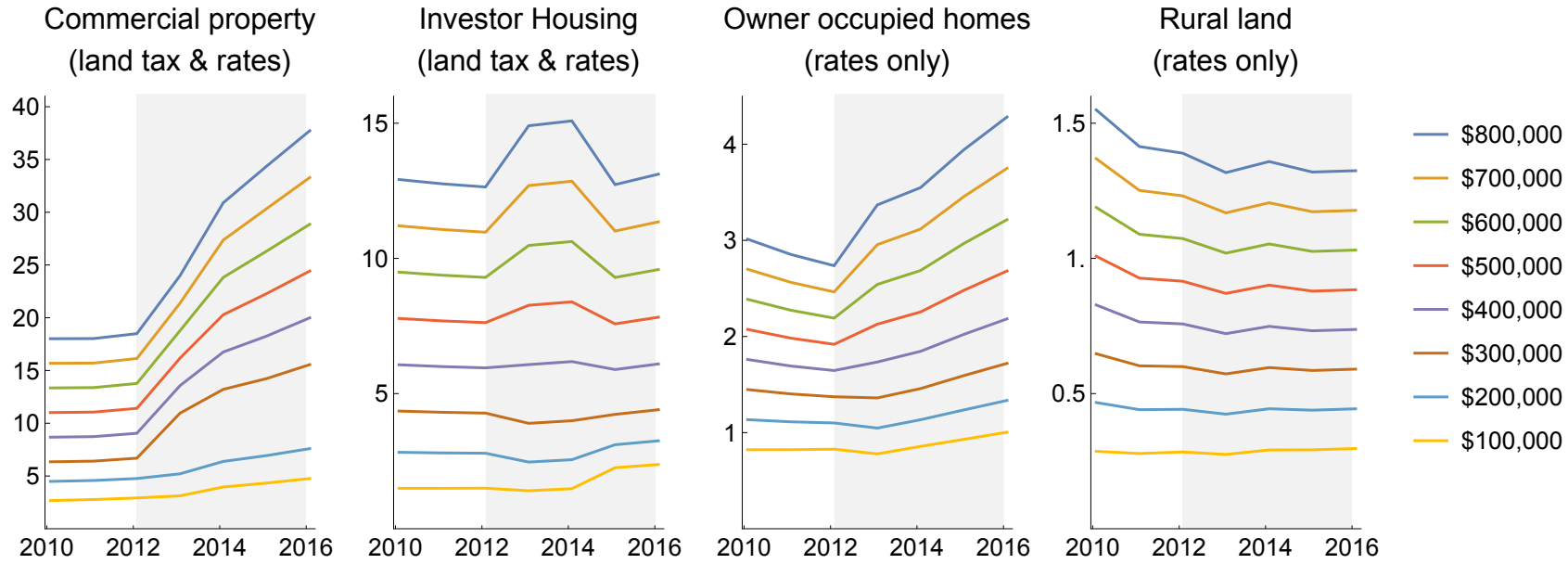

Sources: Authors calculations for each land value from ACT legislation

Values are in \$'000. Effect of changing taxes on land values not considered here. 

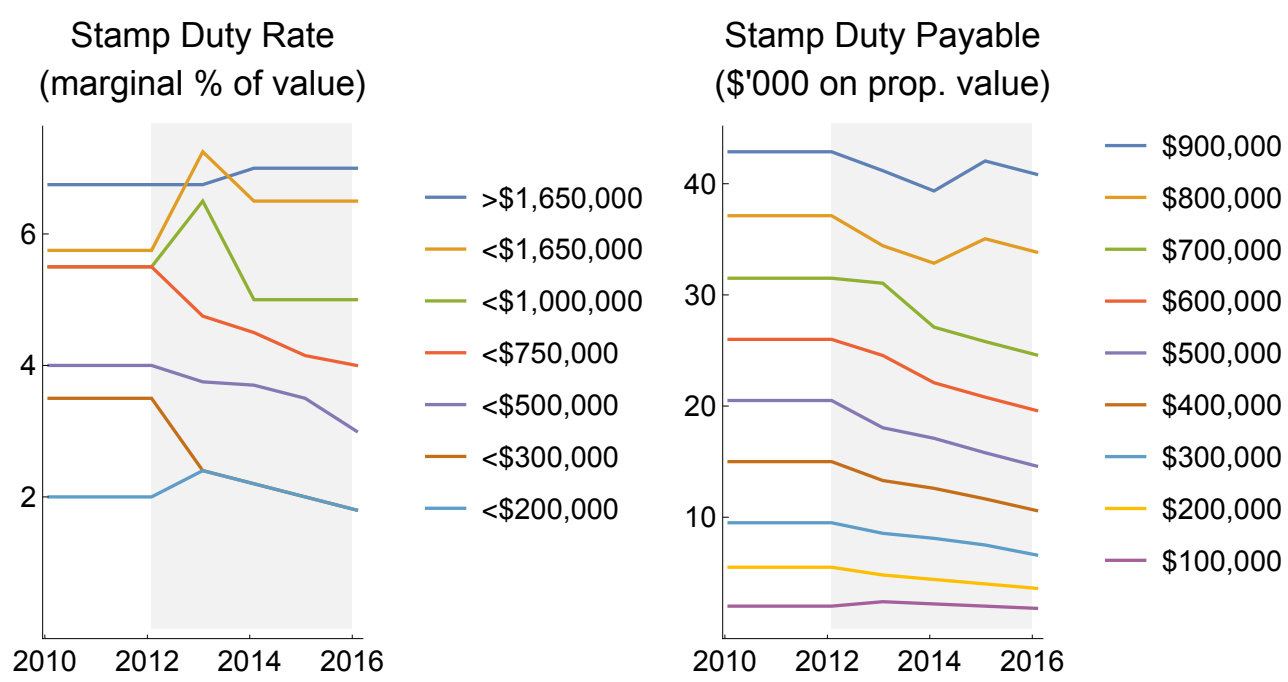

Sources: Authors calculations, Taxation Administration (Amounts Payable- Duty) Determinations 2010-2015. Rates are in \%, values are in \$'000. Effect of changing stamp duty obligations on land values not considered here.

\section{Summary of related reforms}

The main complementary reform has been the gradual reduction in stamp duties on property transactions. Figure 3 shows how the applicable stamp duty rates have become more progressive during the transition period, with the applicable marginal rate falling most for lower value properties, as seen in the left panel. In the right panel the progressive reduction in stamp duty liabilities for property purchasers is more clear. At property value of $\$ 500,000$, the stamp duty liability has fallen from $\$ 20,500$ to $\$ 14,600$ since 2011 . This change assists new buyers in the market, by reducing stamp duty to counteract their future land value tax obligations; an offsetting effect not available to existing landowners not seeking to sell in the near future.

Prior to the reform period, Territory's betterment tax (then called the Change of Use
Charge) policy was a very clean way of diverting economic rents towards taxation revenue at a rate of $75 \%$ of the value gains. However, the uncertainty about value gains when evaluating the options for different potential new uses was a concern for the development industry. The 2011 change codified charges for new use types in different areas of the Territory, which are set with the input of property valuers.

These LVC schedules, which are part of a Disallowable Instrument under the Planning and Development Act 2007, were implemented in 2011, with charges for additional residential dwellings ranging from $\$ 25,000$ to $\$ 130,000$ per dwelling. For commercial and industrial uses, the scheduled charges are levied on a per square meter (sqm) basis, with charges ranging from $\$ 200$ to $\$ 2,000$ per sqm. Revenue from these charges has increased substantially 


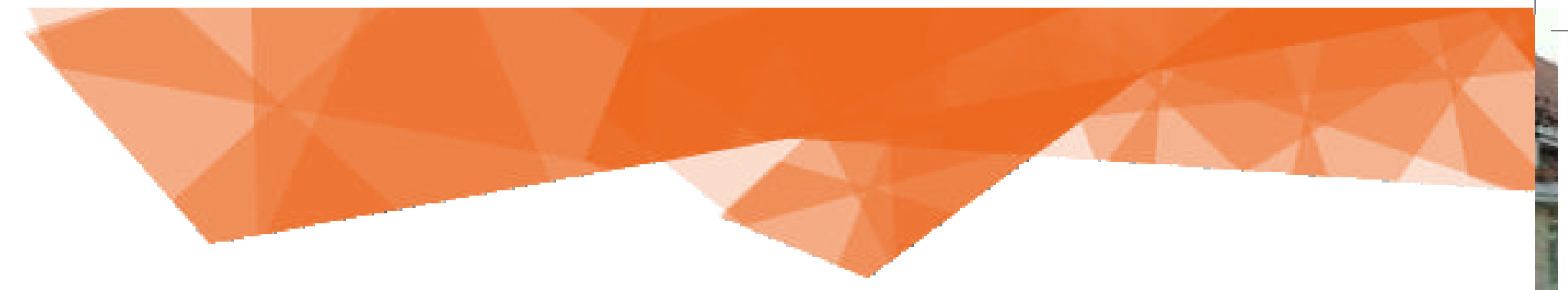

during the reform period, capturing $1.2 \%$ of tax revenue in 2012-13, and resulting in \$19million in revenue during the 2014-15 financial year.

While similar in principle to infrastructure charges that are levied in other States when land is put to higher value uses, these scheduled LVCs are significantly higher, reflecting a political effort to capture the majority of the economic gains from betterment. This in in contrast to Queensland's developer charges system, for example, where attempts by councils to increase charges to cover only future in- frastructure costs lead to substantial lobbying and ultimately the implementation of a cap on developer charges in 2011.

This cap is now $\$ 20,000$ per dwelling with two bedrooms or less, and $\$ 28,000$ for dwellings of three bedrooms or more. If these charges were to reflect the value gains, as they do in the Territory, they would be substantially higher. Certainly the existence and practical success of this system in the Territory is a lesson for planners and Treasury officials in other states.

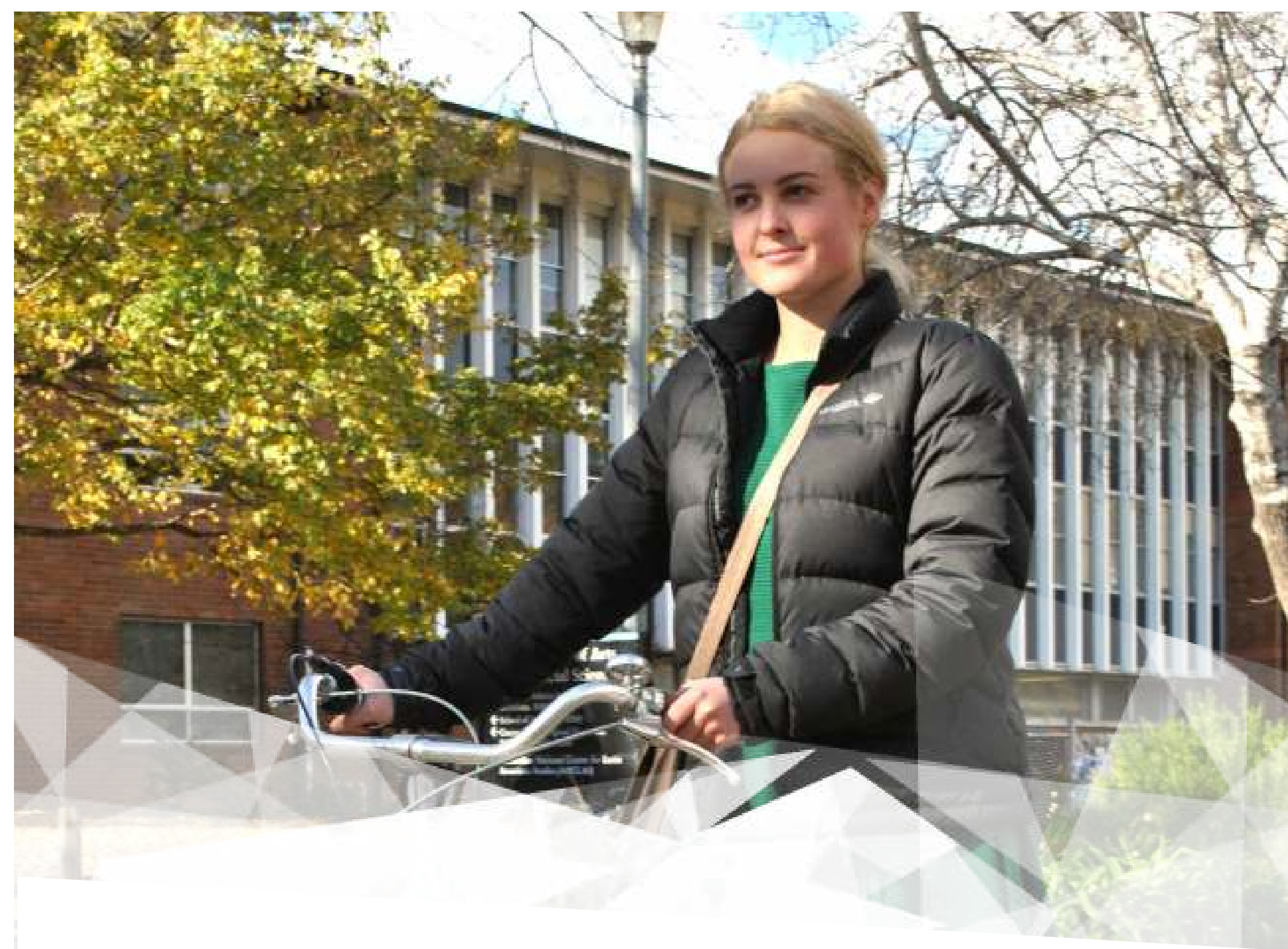



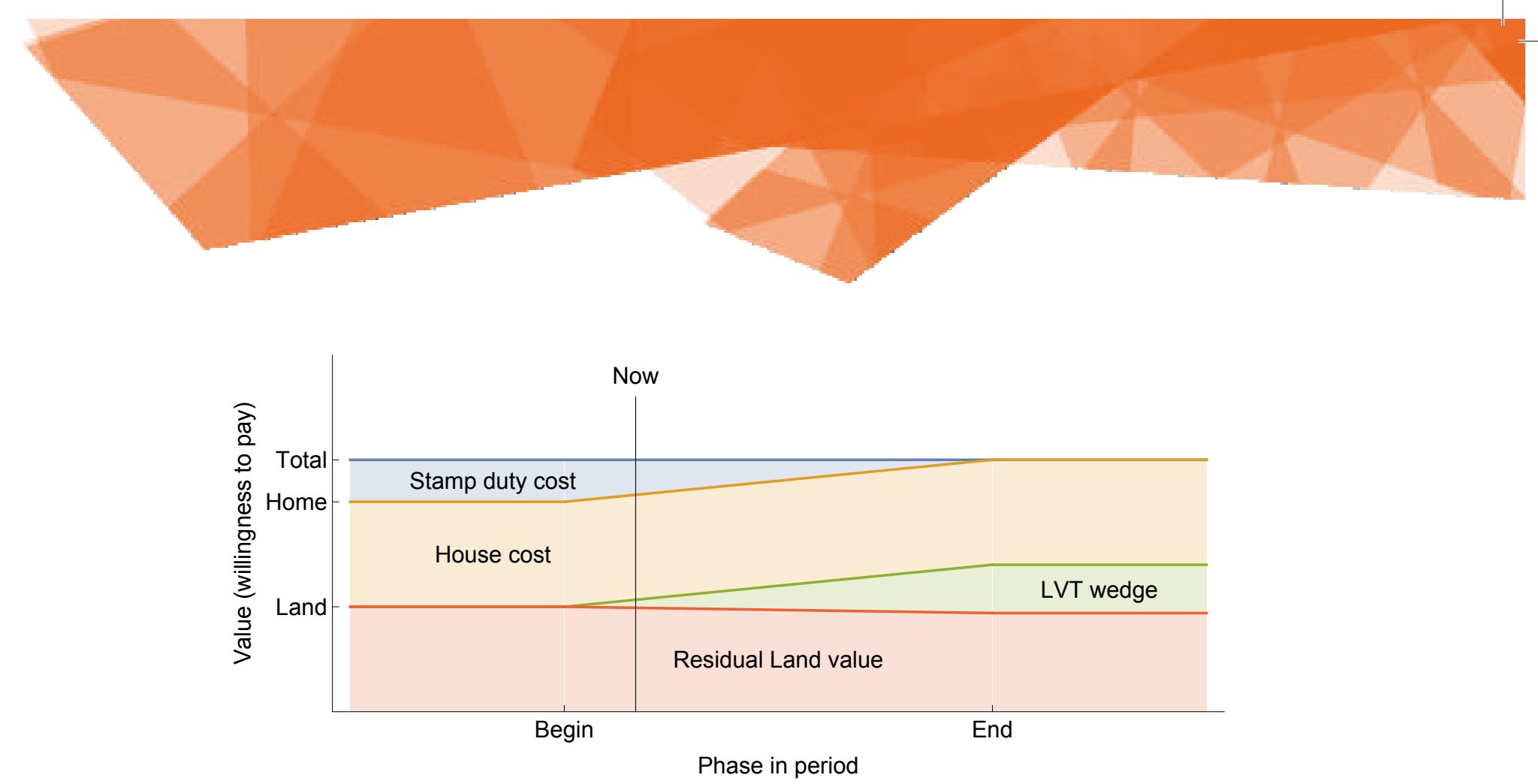

Figure 4: Economic incidence of tax changes during transition period

Even today, the economic case for taxation of land value remains clear cut. The Henry Tax Review made recommendations to move towards these taxes, and economists from across the political spectrum support them. In the modern economic parlance, taxes on economic rents, such as land value taxes, have a low marginal excess burden (or deadweight loss). Put simply, an increase in the rate of this tax does not provide an incentive to change behaviour and make less productive decisions and investments simply in order to avoid paying the tax. If a landholder tries to avoid paying the tax their only option is to sell the land to a new owner who will inherit the tax obligation, and will hence only be willing to pay a price that is lower by the capitalised value of the new tax obligation. Landowners will hence pay the tax either by i) paying the annual tax bill, or ii) paying in the form of lower land prices if they choose to instead sell the land.

Figure 4 above shows how the Territory's approach of phasing in higher land value taxes will see the government capture gains to landowners from decreasing stamp duties that would have otherwise accrued to landowners; the LVT wedge. In theory this change will not impose an additional cost on homebuyers and renters, where the market price will continue to be set by willing buyers and sellers, and not by summation of cost inputs. Only the residual land value will be effected.

Of note here is that because only about $8 \%$ of dwellings are traded in a given year, the revenue requirements each year from stamp duty must come from far fewer property owners than a broad-based land tax. As an example, to raise $\$ 200$ million in revenue from stamp duty on the 12,000 property buyers in the Territory each year requires each to pay $\$ 16,700$, with the effect of this to lower the market price by that amount (the economic incidence of the duty being on property sellers). However, to raise that annual revenue from owners of all 161,000 dwellings in the Territory requires an average payment per dwelling of just $\$ 1,250$ per year. This represents a substantial redistribution of the economic burden of taxation from only the sellers of property, to all property owners. 


\section{Occupier property taxes}

(\% property value)

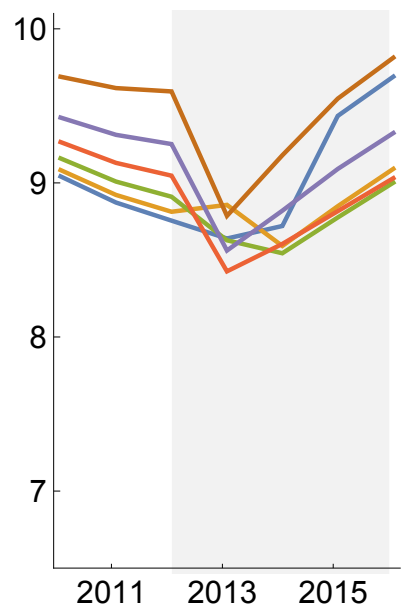

Investor property taxes

(\% property value)

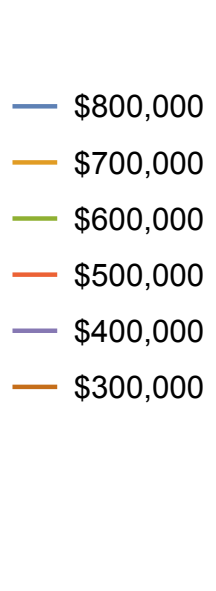

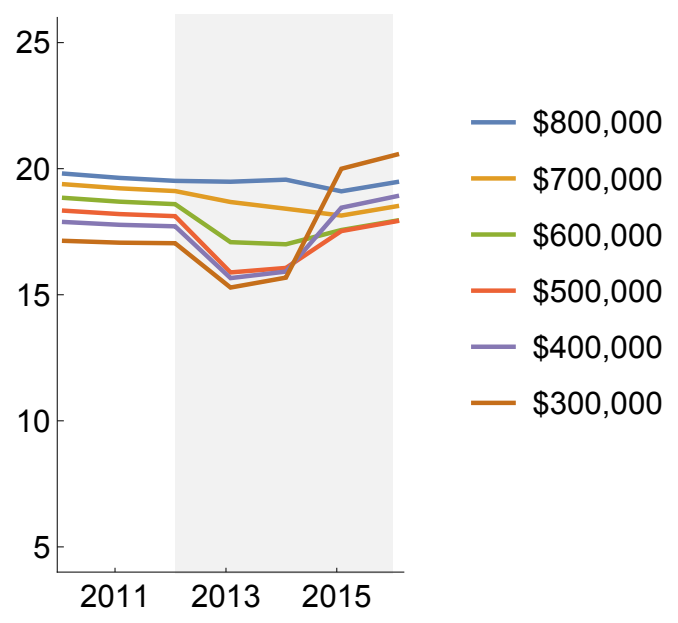

Sources: Authors calculations, with land value at $50 \%$ of property value, and a capitalisation rate of $5 \%$ for general rates and land value taxes.

Figure 5: Net change in capitalised tax obligations

While the effect on transitioning from stamp duty to land value taxes on the distribution of who makes annual tax payments is clear cut, the effect on the capital value of land is not. The effect of higher land value taxes on reducing land values may exceed the effect of increasing land values from lower stamp duties, on balance slightly reducing land values.

We can confirm that this is that case from Figure 5 above. Here, the capital value of total tax obligations for a home buyer as a share of the property value at the time of purchase are calculated, which includes the stamp duty upfront, the ongoing general rates, plus land value taxes for investor owners. Looking through the temporary declines in 2013, the 2012 and 2016 values are quite similar for most property values, indicating that the net overall shift in tax types to date is unlikely to have had a significant price impact on most residential properties. However, it is certainly possible that the market has already factored in expected future increases in land tax obligations into prices, beyond what is calculated here.

Unlike land value taxes, which are unavoidable and hence create no economic distortions, stamp duties on transitions can be avoided by selling and buying homes less often. In an asset market like land, an increase in trading volumes only provides beneficial economic outcomes if very few of the sales in the market occur because of a speculative motive, or simply buying now in the hope of selling at a profit later. Reducing the volume of buyers and sellers who are simply seeking to time the market for the greatest speculative gains is a stabilising role of stamp duties, and in other markets, taxes on transactions, or Tobin taxes, are widely promoted in order to quell speculation. However, if the predominant motive for engaging in land trades is to improve economic output by relocating businesses and households to 


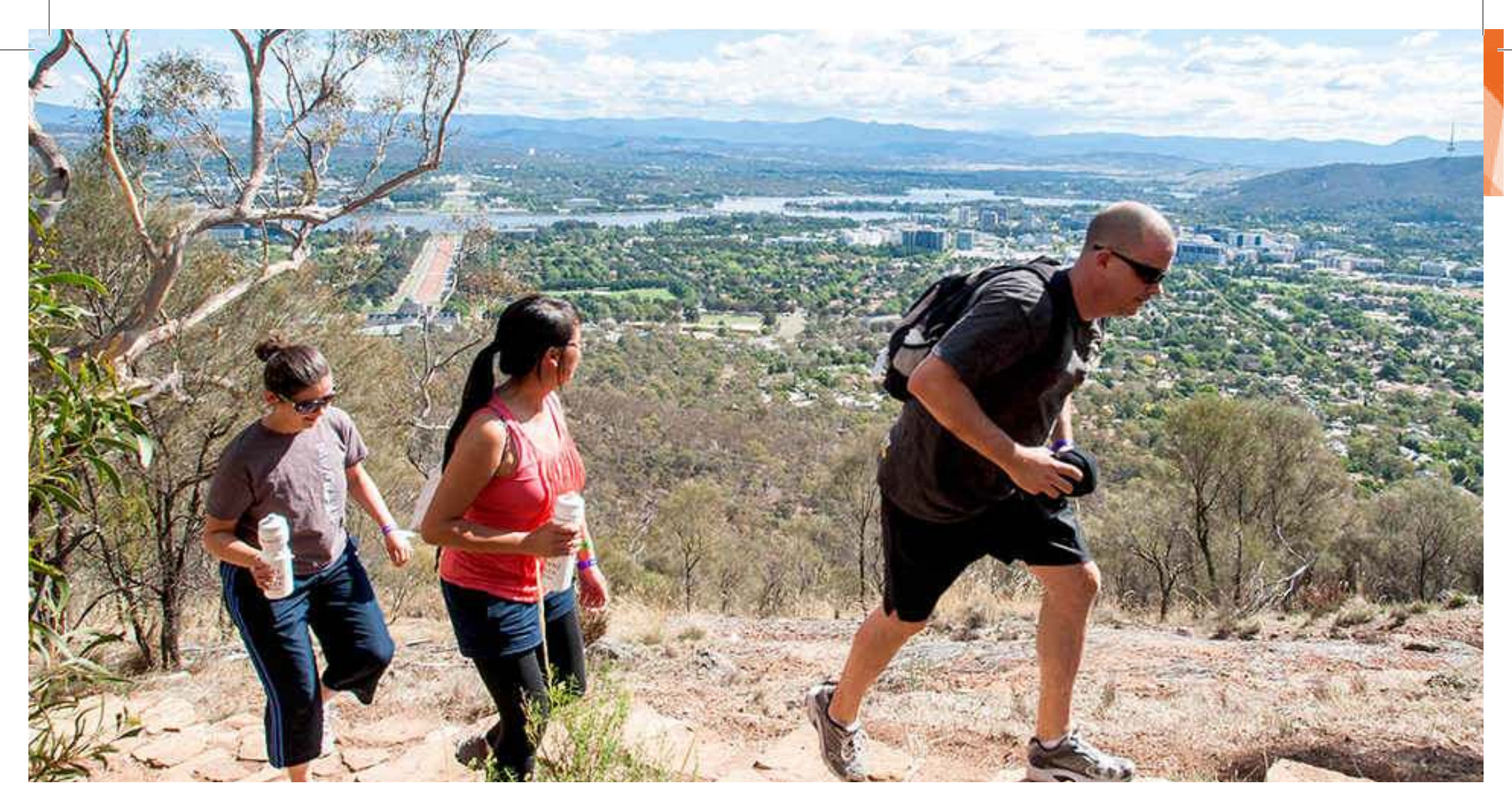

more efficient locations, then limiting these transactions comes at an economic cost.

Ian Davidoff of the International Monetary Fund (IMF) and Professor Andrew Leigh ${ }^{\mathrm{x}}$ of ANU, demonstrated in a 2008 study that the economic incidence of stamp duty is on the seller, and that the incentive to reduce transactions from this tax can be observed in Australian housing data. They showed that indeed, higher rates of stamp duty reduce housing turnover, but also that higher stamp duty rates lead to lower prices - that is, they are paid by the home sellers in the form of lower prices, even though they are administratively paid for by home buyers. Like a tax on land they are incident on the landowner, and like a transaction tax, they reduce the volume of trades.

In terms of the effect on the rate of new housing supply from the introduction of high land value taxes, the theoretical expectation is that the additional costs will not affect the optimal timing of investment by developers. The reason for this is that the rate at which developers sell and develop new housing in the market is set to maximise their revenue, regardless of the various costs they incur. To do otherwise is to leave money on the table.
This can clearly be seen by thinking about the way in which new housing estates are sold. Large estates get planning approvals for many thousands of new lots at a time, yet they do not rush to auction the whole estate the next weekend. They set a price that ensure they sell at a rate that does not depress the local market and sustains the value of the remaining lots. A similar logic applies to rental markets, whereby landlords charge the maximum the market is willing to bear, regardless of the costs they incur.

In all, the expectations derived from economic theory and well-established empirical evidence is that the transition to higher land value taxes will not affect the total cost of buying a home, as the additional tax cost will be offset by lower land prices.

While such taxes have a solid theoretical and moral foundation, the practical matter of shifting from a wide variety of existing taxes, with landowners financially leveraged based on the continuation of the current system, means that outcomes in reality may not align perfectly with the theory. Sudden reductions in land values will be detrimental to landholders who have used their property value to leverage oth- 
er investments, and may be called upon to reduce their debt exposure or offer additional collateral. This is why an early assessment of the Territory's long term experiment is so important for informing future transition paths in other States wishing to adopt a more efficient tax system.

In what follows the primary way in which the effects of the Territory's tax reforms are assessed is by looking at a suite of available data and relevant metrics, and comparing the trends in the Territory against trends in other cities and states. To provide the most reasonable comparisons these metrics are typically normalised to one in July 2012 - the time of the first tax changes - so that relative difference in the time path of each metric is visually obvious.

\section{Government Revenues}

For the perspective of the Territory government there are two main benefits from land value taxes over taxes on transactions. First, as the Review notes, the variability of income from land value taxes is much lower than from transaction taxes. For example, Territory government revenues from stamp duty increased $17 \%$ in $2007-08$, fell $28 \%$ in $2008-09$, only to bounce back with a $44 \%$ increase in $2009-10$. Stamp duty revenues follow the boom and bust pattern of the property market, while the revenue from land value taxes, particularly when they are levied on the 3 year rolling average of land values as they are in the Territory, means that tax revenue is more stable and predictable. This improves the ability to plan for long-term investments that rely on substantial ongoing funding from taxes.

Second, because tax revenue rises in proportion to land value, the Territory government has an incentive to invest in infrastructure and services that maximise the increase in land values, which overall reflects the type of investments that have the largest economic benefits. Thus, over time, it is expected that this new tax system will better align the investment incentives of the Territory government with the economic incentives of the public at large.

At present, the primary effect of the tax reforms has been to shift the Territory govern-

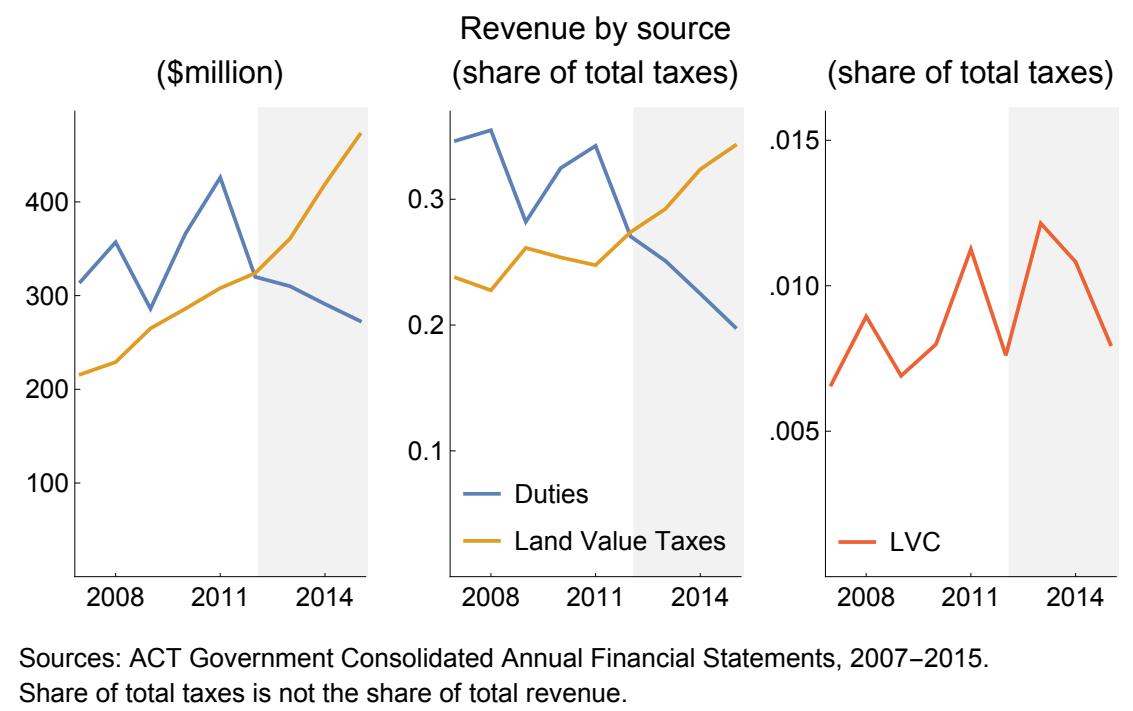

Figure 6: Change to ACT Government revenue profile 


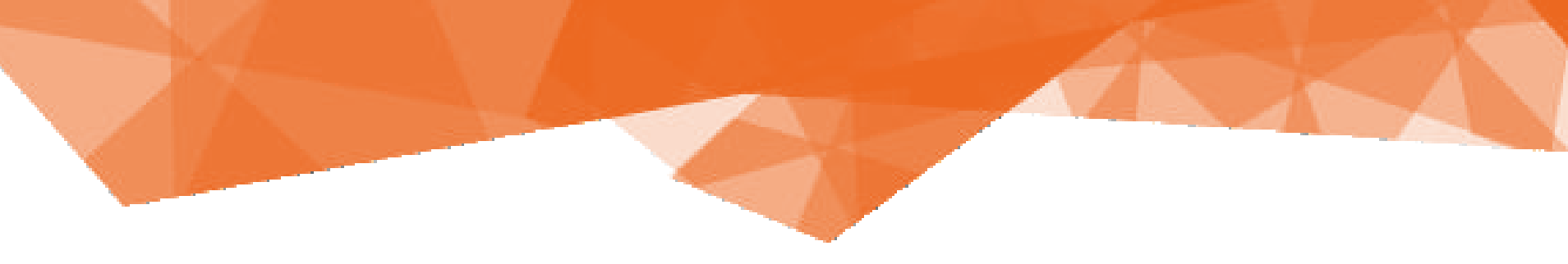

ment's revenue stream towards ongoing rates and land value taxes, as shown in the left two panels of Figure 6. Land value taxes now account for $33 \%$ of tax revenue, while revenues from duties have declined from $35 \%$ to $20 \%$. Overall however, the Territory government still raises around only about $30 \%$ of their total revenue from their own taxation, with the remaining revenue coming primarily from Commonwealth Grants.

Because the tax reforms have only been incrementally enacted for a short period, there is little ability to evaluate their effect on revenue stability. Indeed, the tax transition period has so far coincided with a period of stable or rising property prices, which itself may be partly the result of the tax reforms.
We can compare the share of income from taxes on land value to the combined taxation of local and state governments across Australia, incorporating council rates and state land value taxes. In NSW in $2014-15$ this was $21 \%$ of revenue, down from $24 \%$ in 2010-11. In Victoria and Queensland it was $27 \%$ of revenue, both up from 23\% in 2007-08. Duties make up between $21-27 \%$ of tax revenues in the other states, but this share fluctuates with the property market cycle. While the Territory was relatively dependent on revenue from duties compared to other states, there still appears still to be substantial scope for other states to make similar tax transitions in order to stabilise their tax revenue and align the incentives for government with the common good.

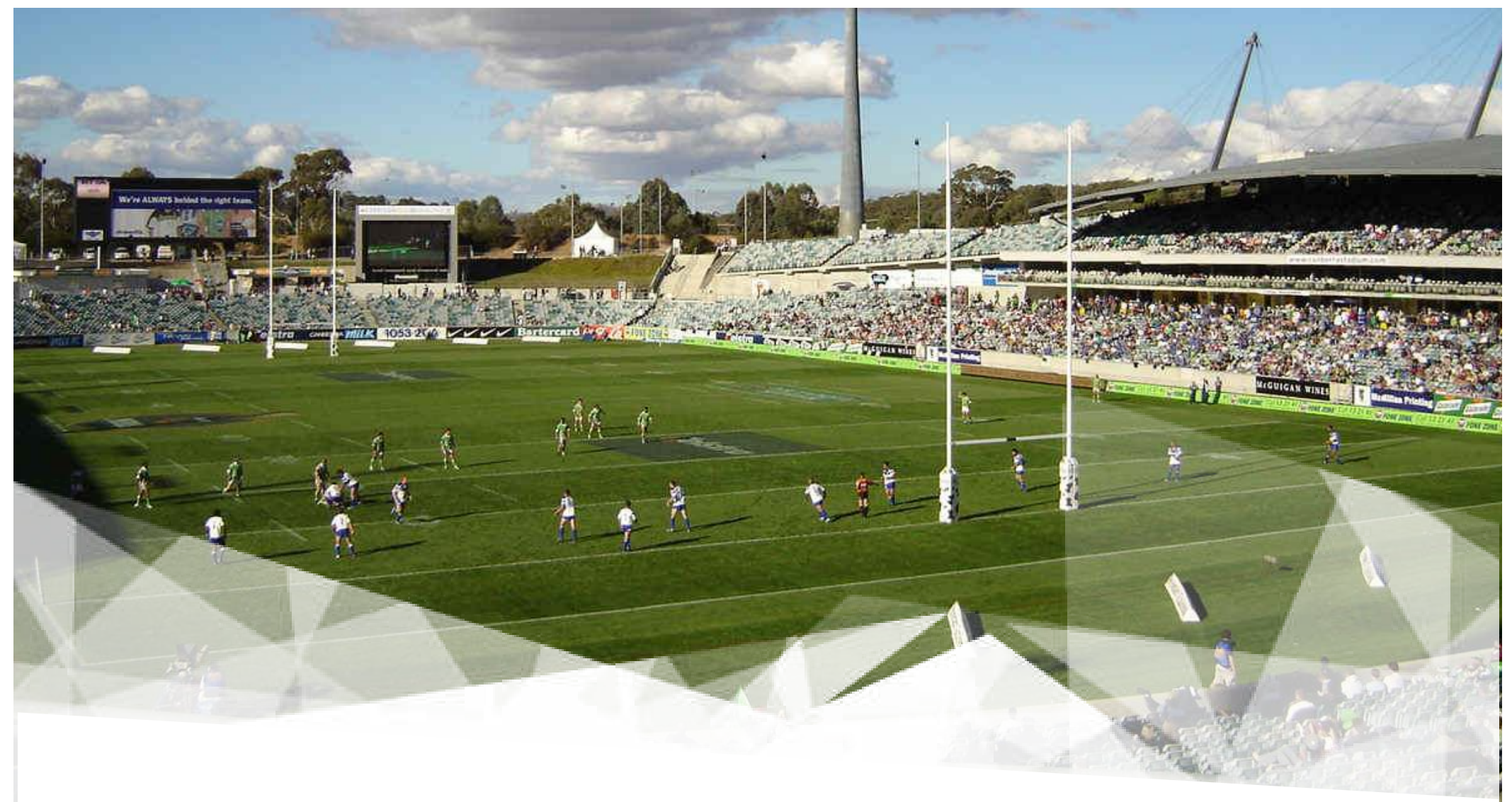



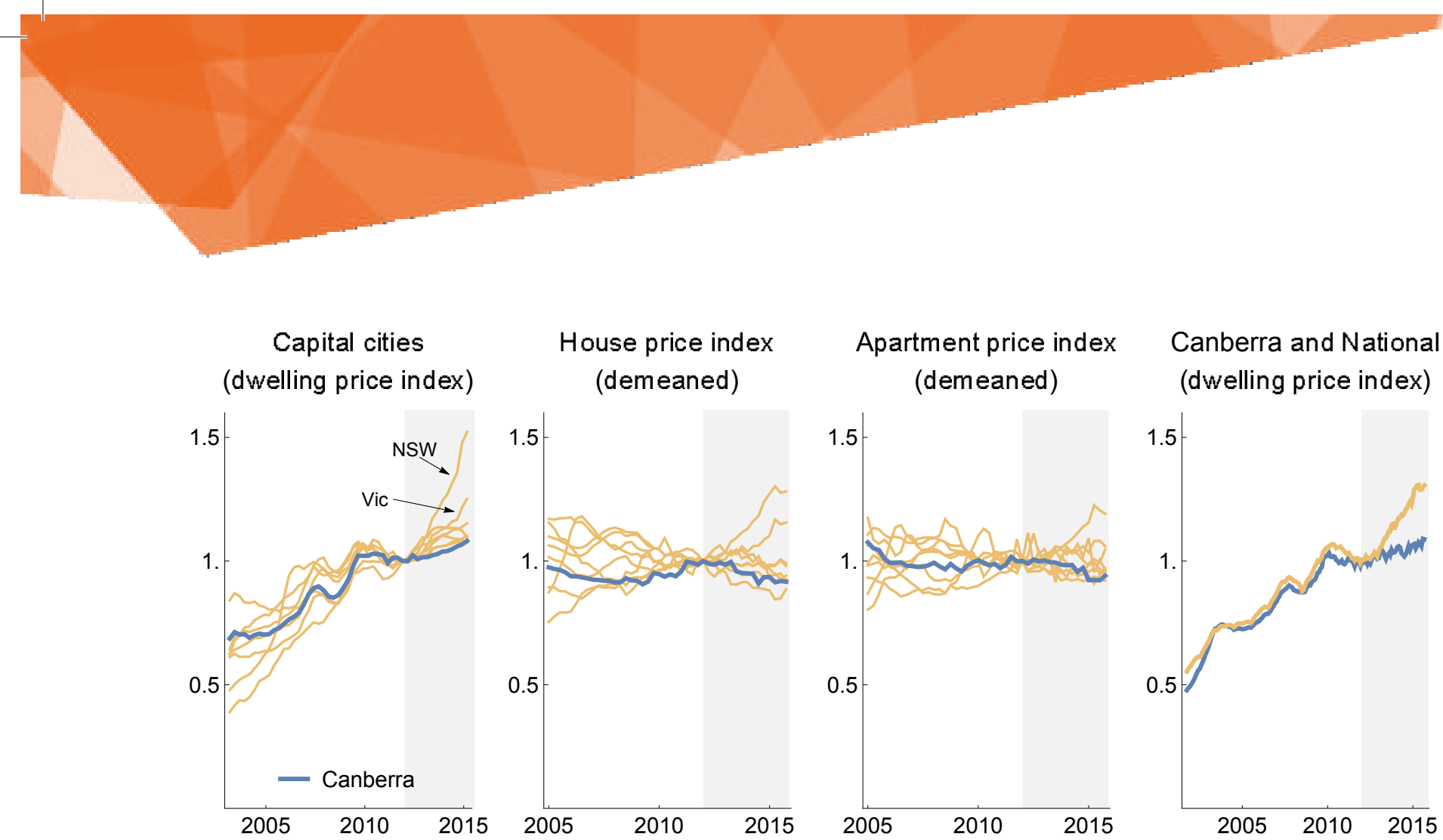

Sources: ABS 6416.0 Residential Property Price Indexes (left panel), CoreLogic RP Data Daily Home Value Index (other panels).

Figure 7: Comparisons of residential property price trends

\section{Residential property ownership market}

Phasing in a higher rate of land value tax during a property boom should constrain price growth, as the higher willingness to pay for land is absorbed into the higher tax obligations, rather than in higher prices and payments to mortgages instead. The available data suggests that this expectation has played out in reality in the past four years in the Territory, though the degree to which this is attributable to tax reforms is difficult to assess.

The left panel of Figure 7 shows the Australian Bureau of Statistics (ABS) residential price index for Australian capital cities since June 2005 , and is indexed to one in July 2012 when the Territory land tax reforms began. Of note is that Canberra saw the lowest home price growth of any capital during the reform period. Using the separate houses and apartments hedonic $^{\mathrm{xi}}$ price indexes from CoreLogic, the time trend is removed from the data in the middle two panels (it is demeaned across time periods), with the relatively low price growth clearly visible in both the detached house and apartment market.

Prior to the reforms the dwelling price growth in Canberra was around the national average, but diverged in the reform period, as seen in the right panel. The data therefore suggests that the increasing land tax obligations are likely to be dampening price growth. If we consider that in the absence of land tax reform that Canberra prices in February 2016 would continue to grow at the national average, then the tax change could have led to prices being 20\% lower than they would have been in the counterfactual world. Given that the current median home price in Canberra is $\$ 535,000$, one could conclude that in the absence of land tax reforms the price may be closer to $\$ 642,000$. For every new buyer, that price reduction results in an annual saving on mortgages repayments of over $\$ 5,000$ per year, along with improving the ease of saving for a deposit by reducing the size of a $20 \%$ deposit by $\$ 21,400$. 

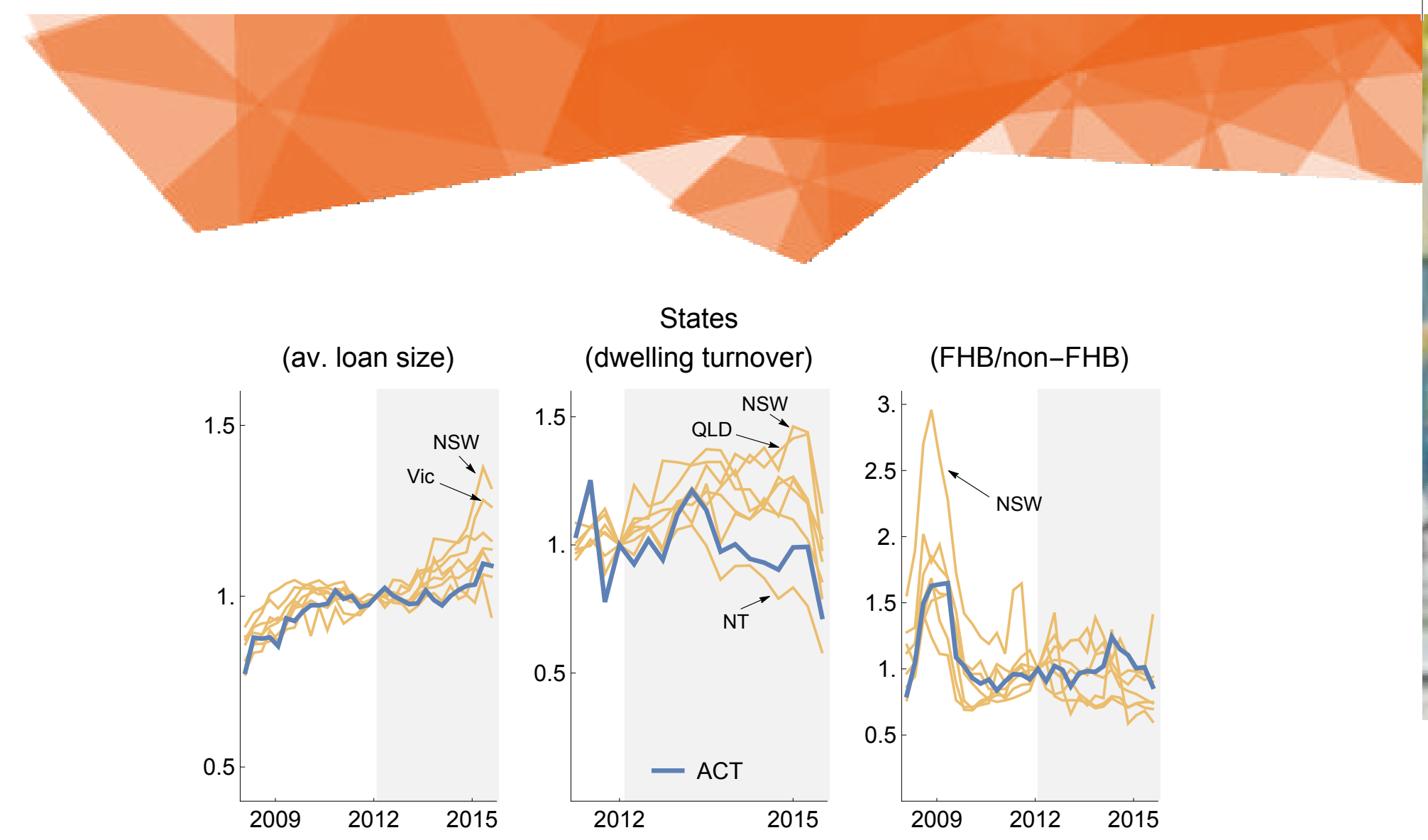

Sources: ABS 6416.0 Residential Property Prices, 5609.0 Housing Finance.

Data is normalised to one in July 2012. Turnover is sales per stock of dwellings.

Shading shows period of land tax reform in ACT.

Figure 8: Housing finance, turnover, and buyer types

In reality it is unlikely that all the relative price declines are solely the result of land tax reforms, and further evidence should be sought to understand the financial effects on homebuyers in practice. To that end, Figure 8 contains panels of charts with data on the average new home loan size, turnover of dwellings as a share of total dwellings, and the ratio of first home buyers (FHB) to other buyers in Australian capital cities.

We see evidence of mortgage savings from the lower prices in Canberra in the left panel, where the size of average new home loans in ACT has grown far less than the other major States since the tax reforms began. Average loan size is up approximately $9 \%$ in ACT since July 2012, while the mean increase for other states is $14 \%$ (or $19 \%$ excluding Northern Territory and Tasmania). With average loan size now $\$ 364,000$ in the Territory, this data suggests that the capitalisation of land taxes into prices may have led to a reduction in average mortgage size in the Territory in the range of $\$ 18,000$ to $\$ 37,000$. In terms of annual mortgage costs, this represents a saving of between $\$ 1,000$ and $\$ 2,200$ per year for the average home.

Taken this evidence together shows is that the increased land tax obligations appear to be keeping prices lower than otherwise would be the case, and perhaps that most of the expected future land value tax obligations for residential property, in the form of increasing general rates, have already been factored into prices. At the median land value of around $\$ 200,000$, the increase in general rates has so far been only about $\$ 220$ per year. However, for high value residential properties, with land values at $\$ 500,000$, the tax reforms have so far increased the annual tax burden by $\$ 640$ per year. If anything these are very small changes for most residential property owners and are 


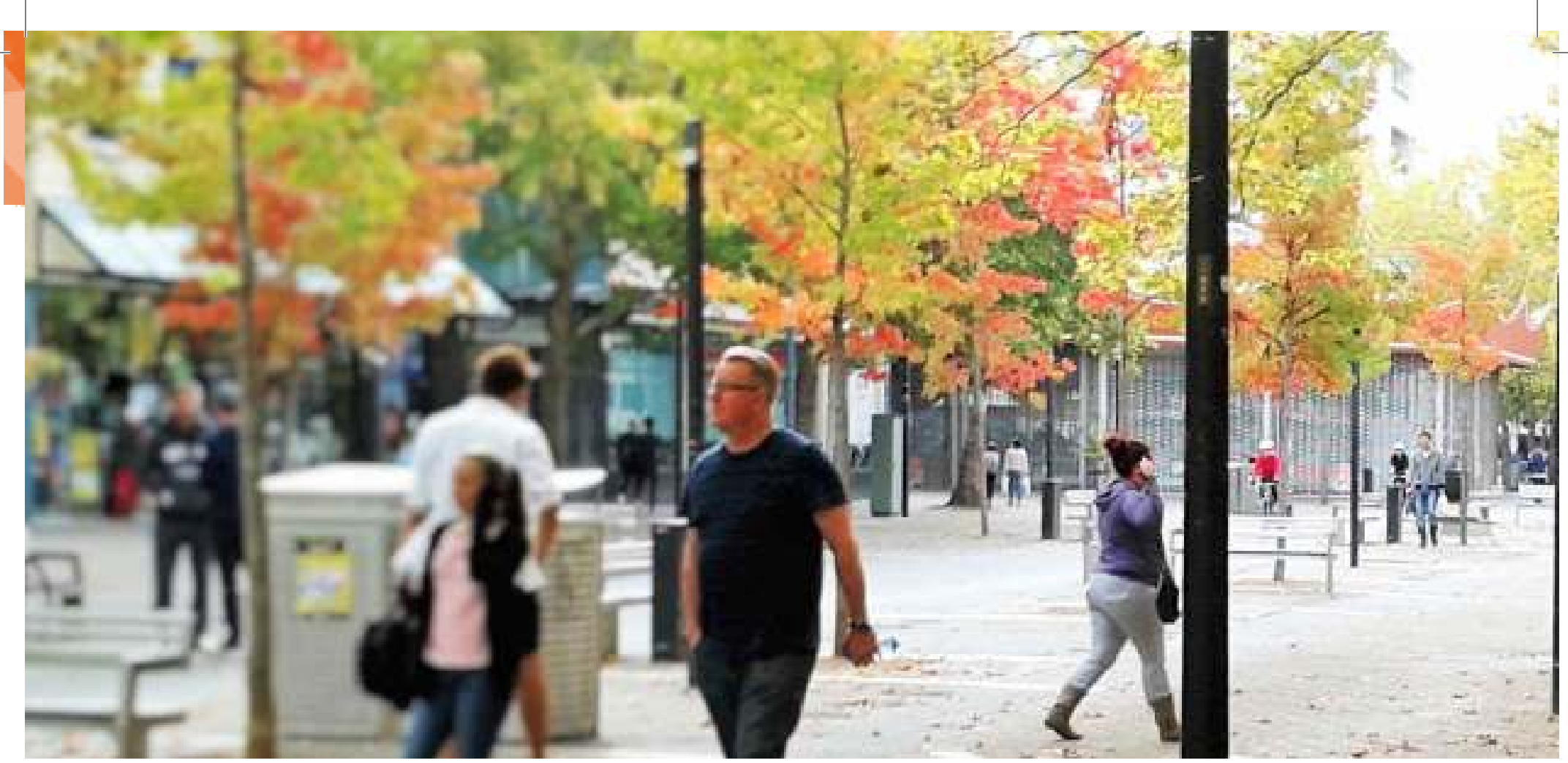

unlikely be the sole cause of the relatively flat prices in Canberra in the past four years. The capitalised value (at 5\%) of those additional costs is only about $\$ 4,400$ for the median dwelling, which is roughly the same as the stamp duty reductions near the median home price. However, with a $2 \%$ increase in future growth in land value tax (general rates) factored in, the present value of tax increases is closer to $\$ 8,000$, which is a little under half the observed relative mortgage size reduction.

Thus, the stability of the Canberra residential property is unlikely to be primarily caused by the direct capitalisation of land value tax obligations into prices. This is instead a secondary factor. If anything, the primary effect of the tax reforms appears to have been to deter speculative buyers from entering the market altogether, which itself has resulted in lower and more stable prices compared to other states.

This explanation is supported by the dwelling turnover statistics in the centre panel of the Figure 8. We see that outside the Northern Territory - a market half the size of the ACT, and which has experienced a property price collapse - the Territory has seen stable and low turnover of dwellings. Compared to other states, they have also seen an above average share of new first home buyers, as seen in the right panel of
Figure 8. Together, these evidence seems to confirm the logic that the ongoing land tax changes are deterring speculative buyers from the Canberra housing market.

\section{Residential rental market}

One of the main effects of increasing the rate of land value tax is to provide incentives for under-utilised land to be put towards its highest value use. In the Territory this effect is limited due to the fact that there is no private market in vacant land, and that the requirements to construct on new land leases ensure that the such incentives are already built into the system.

One change that does have an impact on the incentive to rent dwellings in the market is the shift from the administrative land tax, that was payable by owners of rental properties only while they were rented, to the general rates charge, which is payable by all property owners. Because the previous land tax was payable only if a dwelling was rented, and not if it was vacant, this reduced the cost to owners of keeping a home vacant in order to keep open their speculative options to then sell the property vacant or occupy it only occasionally. Thus, the expectation is that the tax reforms would have 

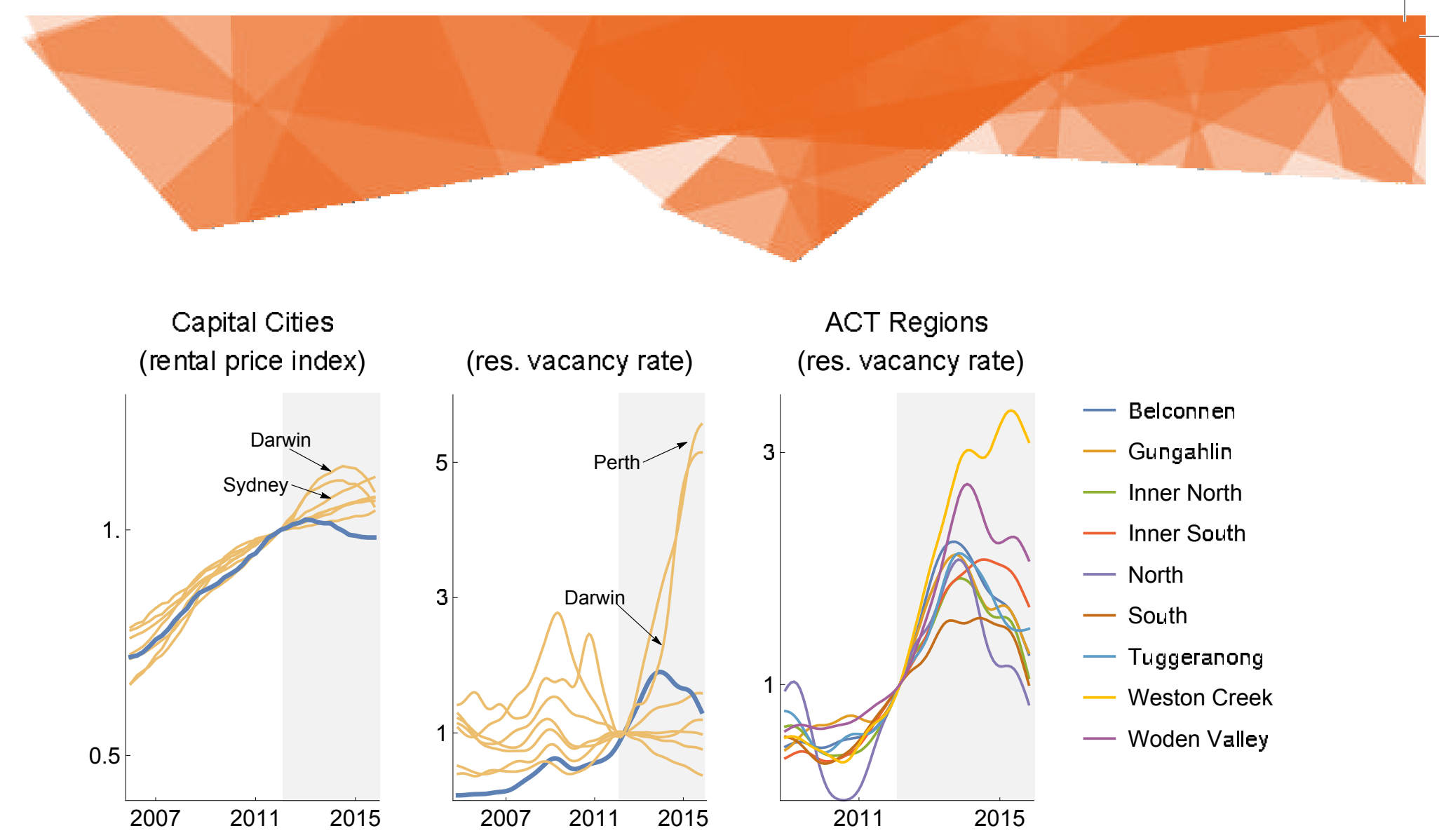

Sources: ABS 6401.0 Consumer Price Index, SQM Research.

All data normalised to one in July 2012. Shading shows period of land tax reform in ACT.

Figure 9: Rental prices and vacancy in Canberra and ACT regions

been beneficial overall for renting households, as the search for tenants by investors should have become more pressing.

Figure 9 summarises the main data available on the Territory residential rental market, comparing it to other capital cities and across Territory regions. Rental prices are the main item if interest here, and in the left panel we can see that Canberra rental prices have fallen the most of any capital city since the start of the land tax reforms. For renters this is very good news. In terms of the economic pressures leading to the rental price declines, the proximate cause is the increase in housing being offered to the rental market relative to new renter demand, the balance of which can be seen in the middle and right panels by way of the vacancy rate, measured as the number of advertised rental properties (advertised for longer than three weeks), divided by the total number of rental properties in the city or suburb.
How much of this is a result of better utilisation of the housing stock is unclear because of the confounding effect of a declining rate of population growth in the Territory since 2012, to now be at its lowest level since 2005. This declining population growth trend is partly the result of lower public sector hiring, which the increase in population and public sector employment since 2014 is seeing population pressure reverse in the rental market, resulting in falling vacancies and stabilising rental prices.

Evaluating whether the land tax reforms will lead to improved rental affordability in the Territory over the long run will require further assessment in the future. At present the size of the change to taxes payable by holders of rental properties is quite minimal, with the ongoing existence of a land tax payable only when the property is rented providing an incentive not to supply under-utilised dwellings to the rental market. 


\section{Residential construction market}

The final key property sector to consider is the market for investment in new construction and home renovations. Because land value taxes are unaffected by the improvements made to a site, they should encourage landowners to maximise the income from their site by making additional improvements. Again, it is worth noting that changes to land value taxes have been modest at this point in the reform period, but looking at the direction of changes in these markets is nevertheless informative, and could reveal unintended consequences.

The available data on dwelling approvals, the value of new construction, and the value of work done on residential alterations and addi-

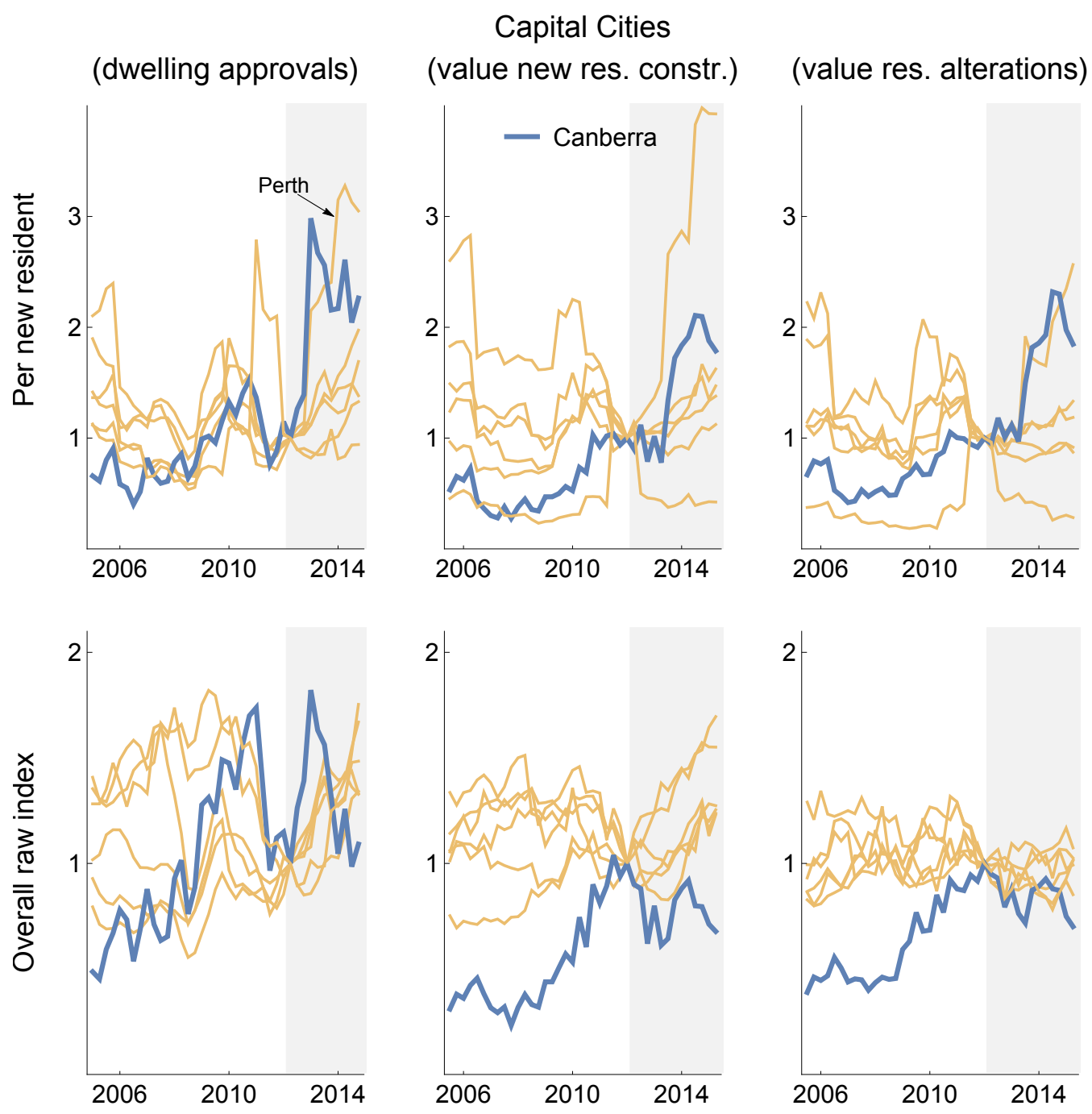

Sources: ABS 3218.8 Regional Population, 8731.0 Building Approvals, 8755.0 Construction Work. Data is normalised to one in July 2012, and is on a "per new resident" basis.

Shading shows period of land tax reform in ACT.

Figure 10: Residential planning approvals, new construction and renovations 


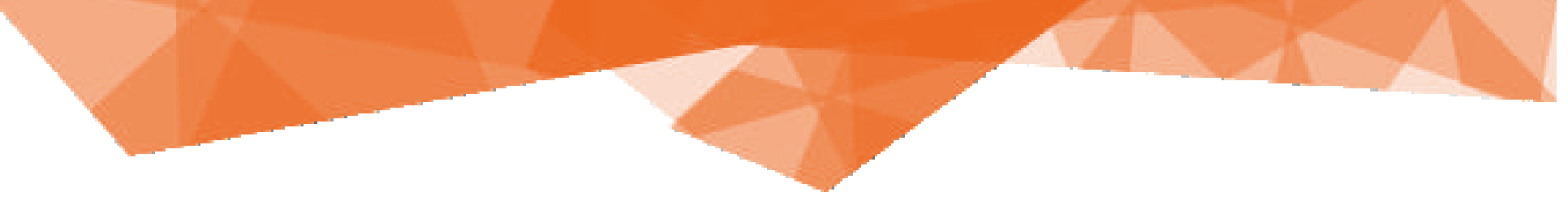

tions is summarised in Figure 10. The top row of panels shows this data on a "per new resident" basis, accounting for the relative amount of new construction compared to new housing need. The lower row of panels shows the overall changes in these data without adjusting for population.

All data are normalised to one in July 2012 to more clearly show the "before" and "after" situations in the Territory.

A number of points are clear in the data. First, prior to the land tax reforms there was a substantial boom in dwelling approvals, which saw a temporary halt as the land tax reforms began, and which has now subsided as population growth rates have declined. The net effect is that Canberra has seen the second highest growth in dwelling approvals per new resident since 2012, behind only Perth.

New construction is also relatively high compared to new residents, which is a contributing factor to the elevated vacancy rate in the rental market. And lastly, in terms of renovations and extensions of the housing stock, Canberra has seen high levels of investment sustained through the reform period. Whether the additional incentive provided by land value taxes on owners to make improvements is a significant part of this story is not clear, though there is no indication of any adverse effect on investment in new housing.

\section{Further considerations as reform progresses}

A number of other considerations necessary to evaluate the tax transition are highlighted here. First, one outcome of the shift away from stamp duty to land value taxes is that home buyers may not fully understand the size of their ongoing tax obligations. This potential information limitation is currently reinforced by the willingness of mortgage lenders to account only for the costs of stamp duty to home buyers, but not ongoing costs of land value taxes. Because stamp duties will soon be zero, and ongoing general rates much higher than today, failure to account for this change in lending practices may mean that more buyers on the margins of creditworthiness will qualify for new loans than they otherwise would. There is a potential here for such lending to increase risk in the local financial system, should no changes be made to mortgage assessment during the transition period.

Secondly, the current reforms appear to have been designed to maintain price stability in the residential property market, particularly for dwellings near the median price. However, for owners of commercial land leases, these changes have had substantial effects on cash flow and capital values. For example, the owner of a commercial land lease with a value of $\$ 800,000$ has seen their tax obligations increase by around $\$ 20,000$ per annum since 2012. With price inflation very low, and asset values in this market falling, the effect of the tax transition is to amplify the poor financial conditions for owners of commercial property. This may become politically important in the coming years as these commercial property owners seek relief from their increasing general rates obligations.

The recently released 2016-17 Budget Papers instead suggest that the major change to the transition path will not be in relation to the rate increases for commercial property, but for residential apartments. Apartment owners currently have a relatively lower land value compared to houses of equal market value, and hence have a lower general rates obligation. The change will see the land tax calculated on the land value for the whole apartment building at the applicable rate, before being apportioned to each apartment owner, rather than apportioning the land value first which would 


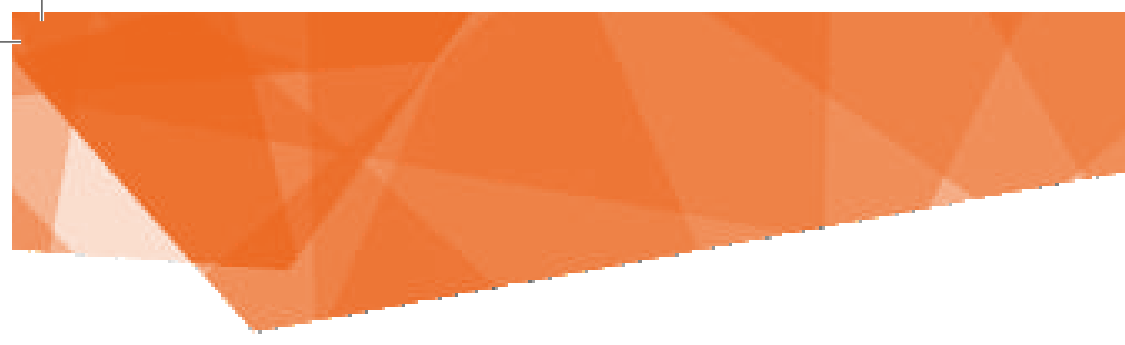

see a lower average tax rate being paid by each apartment owner. The logic of why land value taxes should be in equalised in proportion to market values across dwelling types is not clear, as this outcome can be achieved by simply levying a tax on the total property value rather than the land value.

The reforms also changed incentives for housing investment in particular ways, the effects of which are worth addressing. First is the potential incentive effect from the rising block system of land tax rates, where more valuable properties result in higher average land tax rates. To avoid higher land value taxes, it may be possible for landholders in certain areas to subdivide their land into smaller lots to reduce their total land tax obligations, as the two smaller lots will be charged at a lower average rate. This is a good thing. If this response does arise in the market, this will lead to additional lots being developed.

A second change to incentives comes from the introduction of the Over 60s Home Bonus Scheme in 2014-15, which gives a discounted rate of stamp duty to non-pensioner homeowners to encourage downsizing. The scheme was taken up by 202 applicants in its first year (representing about 3\% of turnover that year). Given that the existing stamp duty concession scheme for pensioners had just 142 applicants in that year (up from 125 in 2013-14, and 90 in 2012-13) it seems likely that the scheme is having a relatively large effect on the targeted households, but it is still a small overall effect on housing choices of older homeowners. What is not known however, is whether the scheme is being used to subsidise older homeowners upgrading to larger homes, to shield their savings from preventing them qualifying for a pension, as well subsidising downsizing.

Lastly, the system of new land releases by the LDA should be considered in relation to this reform. Despite the rate of new housing supply being subject to cycles, and of minimal short term effect on housing affordability, it is the

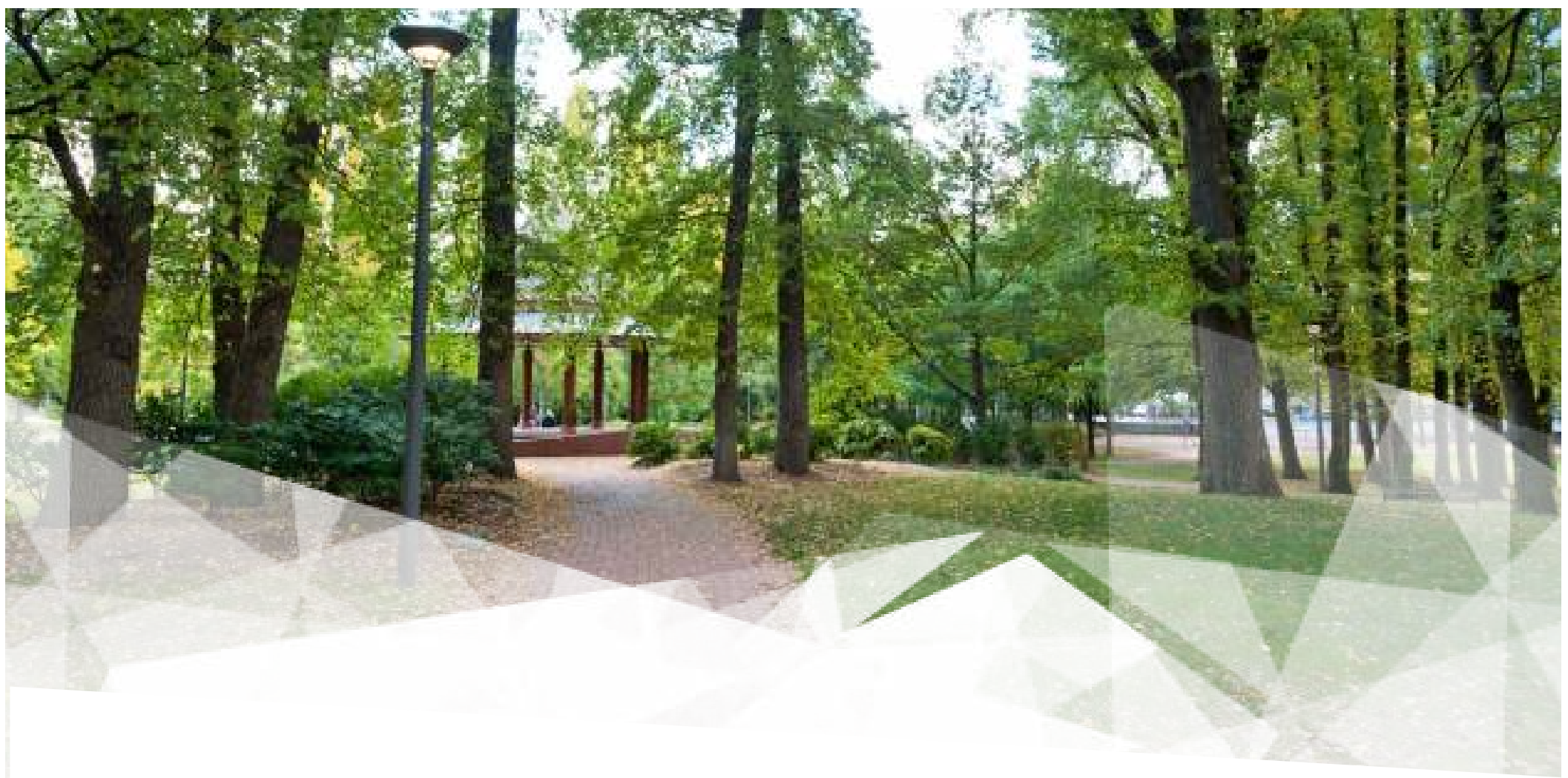




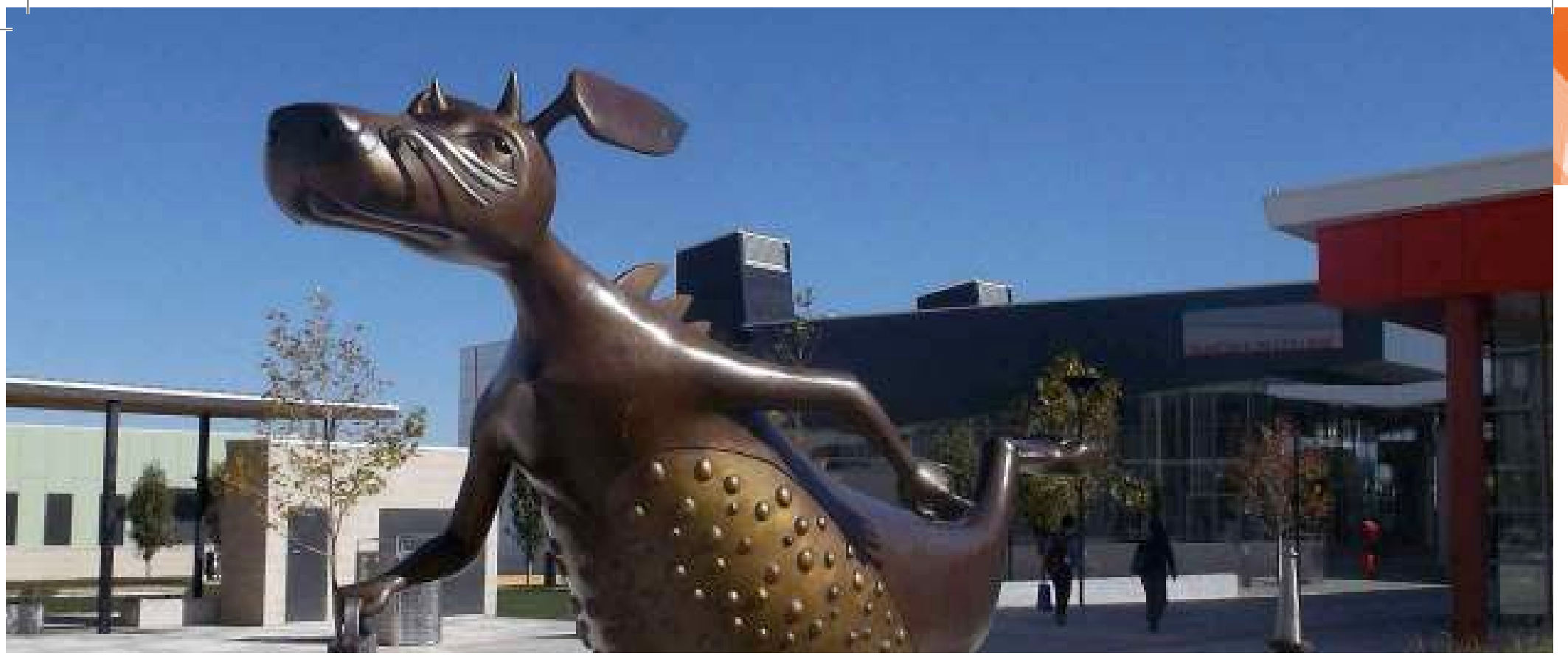

source of long run improvements in the quality and extent of the housing stock. The Land Supply Strategy sets targets for new land releases, and is designed to provide stable and ongoing

\section{Dwelling yield from} LDA land releases

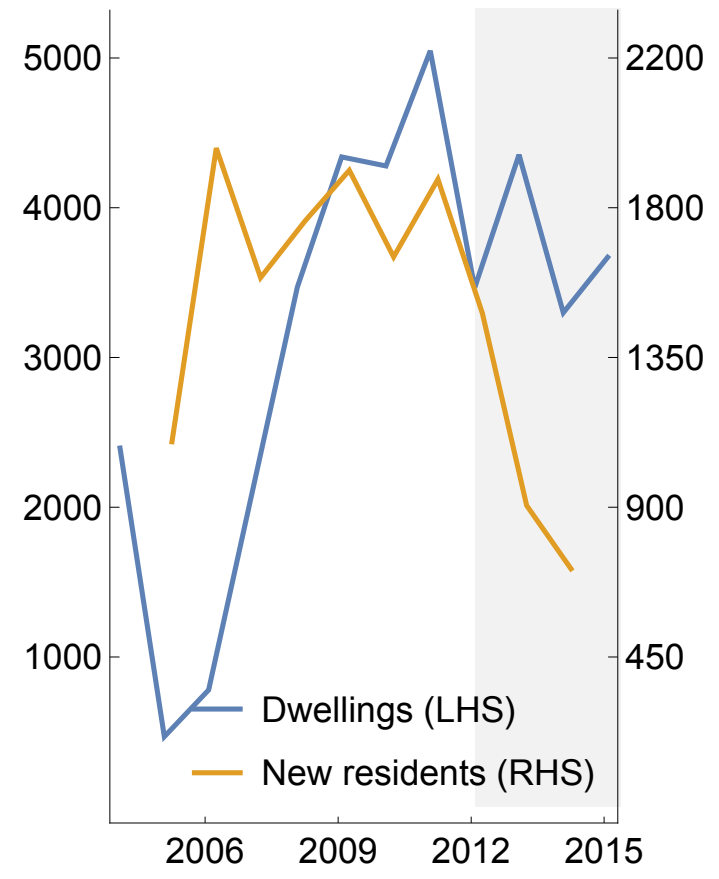

Sources: LDA Annual reports 2005-2015, ABS 3218.0 Regional Populations new supply that meets new population demands, without being disruptive to the market.

In Figure 11 the number of new dwellings arising from land leases by the LDA is summarised. Between 2005 and 2012, a period of relatively high population growth, the LDA appears to have responded with a rapid rise in the release of new dwelling sites. Since the land tax reforms began in 2012 new supply has trended lower, yet at a time when population growth has substantially declined. On a per new resident basis the land release program had its largest releases in the past two years.

However, it should be noted that the relative importance of new supply by the LDA on the city fringes may fall during the remainder of the tax transition period, as a result of densification and new supply from variations to existing leases in established urban areas, which are currently the source of between 5 and $10 \%$ of new dwelling supply.

Together, the LVC and the LDA sale of new land rights generated $\$ 183$ million income for the Territory government in 2014-15. If such schemes were implemented nationally, revenues of around $\$ 11$ billion could be generated in the states, by diverting the windfall planning gains currently given away to private landowners and developers (refer to Appendix for calculation of national revenue).

Figure 11: LDA summary 


\section{Experiment lessons}

The first lesson is that the Territory has a very unique land tenure and planning system. This means that many of the economic benefits of transitioning to a land value tax were already present in the Territory. For example, the incentive for owners of vacant land to make investments on that land has no effect in the Territory, because there is not private land market. The existence of the LVC, and the system of urban land release via the LDA, also demonstrates the clear practical possibility for improving land regulations through betterment taxation, which could be adopted in other states. The efficiency gains from transitioning to land value taxes are therefore likely to be much higher in other states, particularly from the incentive to bring vacant and underutilised land into higher value uses. However, these higher investment incentives can come at a cost to some households who may see their land value change substantially due to zoning decisions. Protection against sudden changes to land values for landholders can be built into a land value tax system by changing the prescribed valuation method for residential property to assume that the current use is the highest and best use.

Second, the impact of a long term land tax transition is likely to be very quickly incorporated into market prices. The data suggests that the abnormally low price growth in the Territory since 2012 is a result of the expected future tax obligations, combined with the effect of deterring speculative buyers in the market, a conclusion arising from the abnormally low housing turnover. The total price effect translates to a $\$ 1,000$ to $\$ 2,200$ per year reduction in mortgage costs for the average new home buyer.
Third, for the construction industry the transition began without adverse effects, while substantial beneficial effects may be expected in other states where the incentive for investment in new housing will be even greater. If anything, the only effect of the tax transition so far on new housing construction was a temporary pause in otherwise relatively high rates of construction, in a similar way to which the introduction of the national goods and services tax (GST) in July 2000 led to some temporal shifts of accounting of construction work in an otherwise healthy market.

Fourth, the tax transition appears well targeted in terms of ensuring price stability and avoiding "bill shock" for residential landowners. Because of this, the impacts have been felt mostly by owners of commercial land leases. This is major redistribution of wealth in the Territory, and is clearly why the reforms have been implemented over a multi-decade time frame. However, it appears on the surface that this redistributive effect may nurture ongoing tension and animosity amongst different landowners, rather than goodwill towards the tax reform, particularly as land value tax rates grow further.

Fifth, potential political conflict between council and state government levels did not exist in the Territory, but may be a substantial barrier to effective reform in other states. In particular, land value taxes and general rates are administered by different levels of government and may both need to be jointly modified in order to simplify the tax system, as has happened in the Territory.

Finally, if such tax changes occurred in other States they would disproportionately burden 


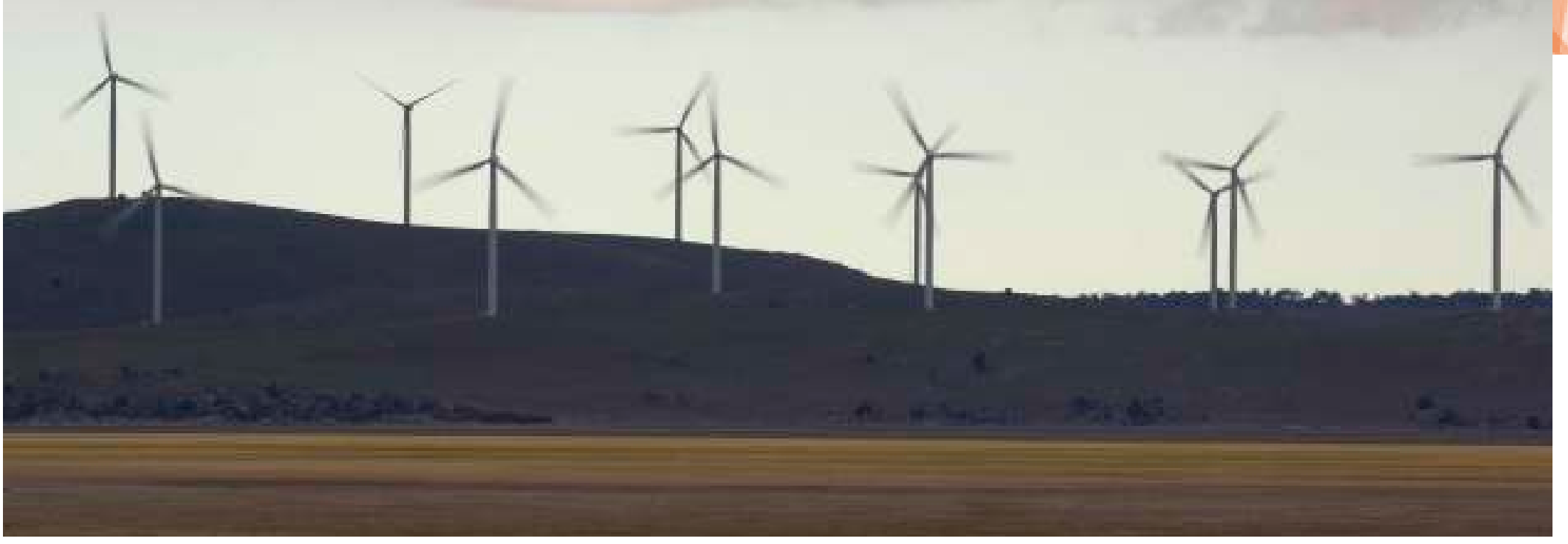

politically influential land-bankers who currently reap multi-billion-dollar windfall gains, and where their business model of delaying the release of new home sites to market is facilitated by existing land tax concessions. For example, in Queensland there is a "land developer's concession" on land taxes for new residential land lots that are approved and subdivided, but not yet on-sold by the developer, which reduced land tax revenues in the State by $\$ 23$ million in 2014-15 according to budget documents.
In sum, the clear aggregate economic efficiency gains from transitioning towards land value taxes are also associated with a substantial redistribution of wealth: away from the wealthiest and most politically-connected groups see a higher tax burden, towards average homebuyers and renters.

The observed economic outcomes confirm the theory, and serve to highlight that the main challenge for adopting these types of reforms elsewhere is political.

\section{Appendix}

The sale of new urban land leases by the LDA provided a dividend to the Territory government \$164 million in 2014-15, while the LVC generated $\$ 19$ million in revenue. To adjust the combined revenue of $\$ 183$ million to reflect the potential gains in other states two adjustments are made. First is to adjust for the dwelling price differences across states. This is achieved with the ratio of capital city median price to Canberra median price to get the price ratio. Second is an adjustment for the number of new dwellings in other states completed in that year to get the dwelling ratio. The total mark-up from the Territory for each state is the price ratio times the dwelling ratio. This mark-up is multiplied by the ACT betterment revenue and then added across states to determine the total revenue potential. 


\begin{tabular}{l|rrrrrr} 
& $\begin{array}{r}\text { MEDIAN } \\
\text { PRICE (2015) }\end{array}$ & $\begin{array}{r}\text { TREND NEW } \\
\text { PRIVATE DWELLINGS }\end{array}$ & $\begin{array}{r}\text { PRICE } \\
\text { RATIO }\end{array}$ & $\begin{array}{r}\text { DWELLING } \\
\text { RATIO }\end{array}$ & $\begin{array}{r}\text { TOTAL } \\
\text { MARKUP }\end{array}$ & $\begin{array}{r}\text { EQUIVALENT } \\
\text { REVENUE (SM) }\end{array}$ \\
\hline SYDNEY & $\$ 691,000$ & 51,368 & 1.39 & 14.13 & 19.57 & 3,581 \\
MELBOURNE & $\$ 502,000$ & 64,529 & 1.01 & 17.75 & 17.86 & 3,267 \\
BRISBANE & $\$ 424,000$ & 42,055 & 0.85 & 11.57 & 9.83 & 1,798 \\
ADELAIDE & $\$ 383,000$ & 10,079 & 0.77 & 2.77 & 2.13 & 389 \\
PERTH & $\$ 528,000$ & 30,343 & 1.06 & 8.35 & 8.83 & 1,616 \\
HOBART & $\$ 299,000$ & 2,734 & 0.60 & 0.75 & 0.45 & 82 \\
DARWIN & $\$ 510,000$ & 1,648 & 1.02 & 0.45 & 0.46 & 84
\end{tabular}

Sources: CoreLogic (prices at May 2015) and ABS 8750.0 - Dwelling Unit Commencements

This calculation is summarised above.

Had the Territory system been enacted in other states, $\$ 11$ billion in revenue would have been raised from the two schemes during the year to June 2015. This is almost the same as the total Queensland government revenue in that year. Instead these gains went to private landowners.

i. ACT Taxation Review, May 2012. Available at http://www.treasury.act.gov.au/documents/ACT\%20 Taxation\%20Review/ACT\%20Taxation\%20Review\%20 May\%202012.pdf.

ii. Australia's Future Tax System Review, with Ken Henry as Chair of the Review panel. Details are at $h t t p: / / t a x r e v i e w$. treasury.gov.au/Content/Content.aspx?doc=htm//home.htm.

iii. 2012-13 Taxation Reform. Available at http://treasury.act. gov.au/budget/budget_2012/files/budgetpaper3/03_2taxationreform.pdf

iv. A comprehensive history of the Territory's leasehold tenure system is available on the Prosper website https://www.prosper.org.au/2008/01/16/canberra/.

v. These requirements are outlined in the Memorandum of Provisions relevant to that particular leasehold title, under Section 103A of the Land Titles Act 1925.

vi. A recent study showed that in Queensland for instance, well-connected developers gained the lion's share of planning gains from rezoning decisions, worth over $\$ 710$ million from just six planning changes. Murray, C.K. and P. Frijters. 2016. Clean money, dirty system: Connect- ed landowners capture beneficial land rezoning. Journal of Urban Economics. Volume 93, May 2016, Pages 99-114. Available at http://papers.ssrn.com/so/3/papers. cfm?abstract_id=2604397

vii. The scale of land-banking in other states is astonishing Estimates by Prosper Australia in the 2014 Englobo Report show that the top eight land developers had 272,000 residential land sites in their possession. Report available at $h t t p s: / / w w w . p r o s p e r . o r g . a u / 2014 / 10 / 31 /$ land-banking-profits-during-a-housing-supply-crisis-englobo-2014/.

viii. According to Australian Bureau of Statistics, 6523.0 Household Income and Wealth, Australia, 2013-14. Available at http://www.abs.gov.au/ausstats/abs@.nsf/ $\mathrm{mf} / 6523.0$.

ix. The Gini coefficient is a measure of the dispersion of incomes, where 0 is totally equal incomes across a population, and 1 is totally unequal (a single person has the whole aggregate income).

x. Davidoff, I., and A. Leigh. 2013. "How do stamp duties affect the housing market?." Economic Record 89.286 (2013): 396-410. Available at http://www.econstor.eu/ bitstream/10419/80681/1/750074574.pdf. Andrew Leigh is now the Federal member for Fraser.

xi. A hedonic price index improves on other price indexes such as the median, by controlling explicitly for the different quality attributes of each property in the index, and thus provides a better picture of the underlying land asset price movement. 
